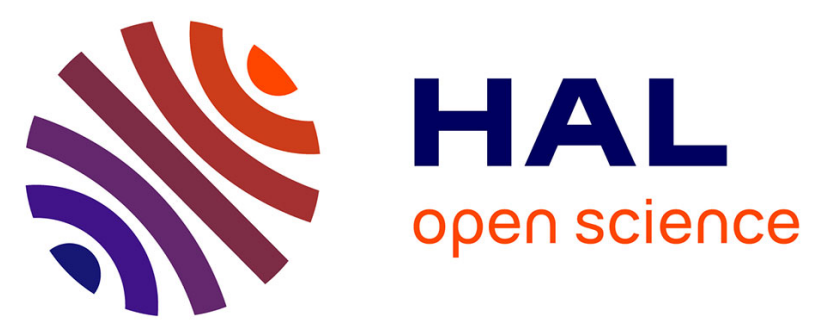

\title{
Multiple values of isolated and clusters of Ficus tree species protected by Betsileo farmers in rural landscapes in Madagascar. Implications for biodiversity conservation
}

Verohanitra M Rafidison, Bakolimalala Rakouth, Stéphanie Carriere, Finn

Kjellberg, Yildiz Aumeeruddy-Thomas

\section{To cite this version:}

Verohanitra M Rafidison, Bakolimalala Rakouth, Stéphanie Carriere, Finn Kjellberg, Yildiz Aumeeruddy-Thomas. Multiple values of isolated and clusters of Ficus tree species protected by Betsileo farmers in rural landscapes in Madagascar. Implications for biodiversity conservation. Biodiversity and Conservation, 2020, 29, 10.1038/s41559-017-0349-6 . hal-02416531

\author{
HAL Id: hal-02416531 \\ https://hal.science/hal-02416531
}

Submitted on 17 Dec 2019

HAL is a multi-disciplinary open access archive for the deposit and dissemination of scientific research documents, whether they are published or not. The documents may come from teaching and research institutions in France or abroad, or from public or private research centers.
L'archive ouverte pluridisciplinaire HAL, est destinée au dépôt et à la diffusion de documents scientifiques de niveau recherche, publiés ou non, émanant des établissements d'enseignement et de recherche français ou étrangers, des laboratoires publics ou privés. 


\section{Biodiversity and Conservation}

\section{Multiple values of isolated individuals of Ficus tree species protected by Betsileo farmers in rural landscapes in Madagascar. Implications for biodiversity conservation --Manuscript Draft--}

\begin{tabular}{|c|c|c|}
\hline Manuscript Number: & \multicolumn{2}{|l|}{ BIOC-D-19-00008R2 } \\
\hline Full Title: & \multicolumn{2}{|c|}{$\begin{array}{l}\text { Multiple values of isolated individuals of Ficus tree species protected by Betsileo } \\
\text { farmers in rural landscapes in Madagascar. Implications for biodiversity conservation }\end{array}$} \\
\hline Article Type: & \multicolumn{2}{|l|}{ Original Research } \\
\hline Keywords: & \multicolumn{2}{|c|}{$\begin{array}{l}\text { Ficus; Madagascar; local knowledge; social-ecological systems; traditional practices; } \\
\text { forest corridor; biodiversity; collaborative approaches }\end{array}$} \\
\hline Corresponding Author: & \multicolumn{2}{|l|}{$\begin{array}{l}\text { Yildiz AUMEERUDDY-THOMAS, PhD } \\
\text { Centre National de la Recherche Scientifique } \\
\text { FRANCE }\end{array}$} \\
\hline \multicolumn{3}{|l|}{$\begin{array}{l}\text { Corresponding Author Secondary } \\
\text { Information: }\end{array}$} \\
\hline Corresponding Author's Institution: & \multicolumn{2}{|l|}{ Centre National de la Recherche Scientifique } \\
\hline \multicolumn{3}{|l|}{$\begin{array}{l}\text { Corresponding Author's Secondary } \\
\text { Institution: }\end{array}$} \\
\hline First Author: & \multicolumn{2}{|l|}{ Verohanitra M. RAFIDISON, PhD } \\
\hline \multicolumn{3}{|l|}{ First Author Secondary Information: } \\
\hline \multirow[t]{5}{*}{ Order of Authors: } & \multicolumn{2}{|l|}{ Verohanitra M. RAFIDISON, PhD } \\
\hline & \multicolumn{2}{|l|}{ Bakolimalala RAKOUTH, PhD } \\
\hline & \multicolumn{2}{|l|}{ Stéphanie M. CARRIĖRE, PhD } \\
\hline & \multicolumn{2}{|l|}{ Finn KJELLBERG, PhD } \\
\hline & \multicolumn{2}{|l|}{ Yildiz AUMEERUDDY-THOMAS, PhD } \\
\hline \multicolumn{3}{|c|}{ Order of Authors Secondary Information: } \\
\hline \multirow[t]{2}{*}{ Funding Information: } & $\begin{array}{l}\text { ECOFOR } \\
\text { (Ecofor (Groupement d'Intérêt Public pour } \\
\text { les écosystemes forestiers).) }\end{array}$ & Dr. Finn KJELLBERG \\
\hline & $\begin{array}{l}\text { SCAC Ambassade de France à } \\
\text { Madagascar } \\
\left(\_\right)\end{array}$ & Dr Verohanitra M. RAFIDISON \\
\hline Abstract: & \multicolumn{2}{|c|}{$\begin{array}{l}\text { In Madagascar, biodiversity, local livelihoods and agroecosystems are increasingly } \\
\text { threatened. It is critical to understand and support local social-ecological systems that } \\
\text { sustain livelihoods and value biodiversity. This study investigates why Betsileo } \\
\text { communities in Ambendrana and Sahabe protect isolated individuals and clusters of } \\
\text { Ficus species in their rural landscapes. Ficus trees have multiple values and sustain } \\
\text { webs of ecological interactions that favor biodiversity. We show that spontaneous } \\
\text { seedlings of Ficus are protected and that people also actively propagate Ficus by } \\
\text { stem cuttings. Their multiple values and uses and the distribution patterns of each } \\
\text { species, are linked to social-ecological dynamics and to the historical construction of } \\
\text { local landscapes. Both past and present uses associated with each Ficus species } \\
\text { define how they are protected. Different sets of practices associated with each species } \\
\text { are governed by both material and symbolic considerations. Ficus reflexa, a } \\
\text { boundary marker of zebu corrals, has a symbolic role in protecting humans and } \\
\text { livestock and checks erosion; F. lutea is a marker of residences of ancient noble } \\
\text { classes and F. tiliifolia is a remnant of swidden agriculture and a marker of the } \\
\text { memory of ancestors, but its numbers are shrinking. Ficus trees are protected but } \\
\text { there is no strict taboo against cutting them when they hinder crop production. Their } \\
\text { potential role for biodiversity conservation is linked to these social-ecological dynamics. } \\
\text { Based on these findings, we propose some rules of thumb for developing collaborative }\end{array}$} \\
\hline
\end{tabular}


approaches which consider synergies between local and scientific knowledge.

Response to Reviewers:

Responses to reviewer 1: Many thanks for your detailed comments and your thoughtful visions that have helped us clarify our statements. Please find below our responses: 1."you repeatedly talk about „noble", ,poor" and „ordinary" social classes who have different access rights to different Ficus trees. I am aware that in many Malagasy societies caste systems are in place but many readers are not, so i would suggest that you explain this early in the introduction and also relate these groups ethnically, in power and its socio-cultural context".

We have responded to this comment. Please see lines 92-127.

2. "You don't really study anything about livelihoods, therefore, i would remove this from all parts of the manuscript, i.e. for sustaining "biodiversity and livelihoods", it is certainly not the case that this is always mutually beneficial.Yu would have had to give this a framework , i.e. „sustainable livelihoods" or similar but you do don't. As it is now , it is not clear what is meant. Livelihoods mean different things to economists, geographers and social scientists".

In the introduction (lines 81-94), we explain the following : (1) that livelihoods are very strongly linked in Madagascar to biodiversity. We explain that human activities in Madagascar have driven deforestation. There is thus no ambiguity in our statements. We do not imply that biodiversity and livelihoods necessarily have positive effects on each other. When we say the following: "The current decline in the rule of law in Madagascar could greatly harm biodiversity and local livelihoods", we clearly mean that local livelihoods are highly dependent upon biodiversity. We do not say that local livelihoods necessarily sustain biodiversity. The whole paper in fact aims at identifying specific connections between people and some elements of biodiversity, in this case Ficus species, that could potentially help sustain biodiversity while also sustaining livelihoods. The roles of Ficus as keystone species that can potentially enhance the conservation of biodiversity are fully recognized in literature that we mention.

Furthermore, as ethnoecologists, and not "social scientists" ( ethnoecology combines ethnology and approaches in ecology), we do not consider that livelihoods are independent from ways people perceive, use, and manage Ficus species within their rural landscapes. In this particular case, these elements of biodiversity have impacts on soil (fertilization) and water, impacts on feeding habits of children (much work on food systems shows that children access foods that adults do not use and that this often neglected part of their diets contributes nutrients essential to their health), on culture and interpersonal relationships, and on people's beliefs and religion. It is fully recognized that human well-being is linked to all these dimensions of livelihood (cf Sustainable Development Goals, also see Sterling et al. 2017). We therefore consider that our use of the term "livelihood" fits with the content of this paper and cannot be removed.

Sterling, E. J., Filardi, C., Toomey, A., Sigouin, A., Betley, E., Gazit, N., ... Stege, K. (2017). sustainability indicators across scales. Nature Ecology \& Evolution, 1(December). https://doi.org/10.1038/s41559-017-0349-6

3. « the frameworks about "nature" and „biodiversity" are inconsistently used throughout the manuscript. Given the (partly) social science approach of this paper, this needs more clarity and I would expect this section to be a bit more critical. Nature is a social construct, according to most social scientists, whereas biodiversity is not, which is much narrower defined but also includes many other things beyond tree diversity »As ethnoecologists, we do not use « Nature » only as a social construct, but we use a precise definition (given on lines 96 -100) and we explain how the concept of nature that we use relates to biodiversity. We do not wish to remove the word biodiversity from the paper, because it is clear that when we speak of a species of Ficus with a scientific name, its position in a landscape, and how people relate to it, we do consider it as an element of biodiversity to which people refer to very precisely, even though vernacular classifications may differ from scientific ones.

Malagasy rituals, traditions and beliefs are around nature but NOT about biodiversity, this is an interpretation, and many anthropologists and social scientists will not agree with this statements. Either remove it or back it up with more discussion and references. Explained above and references added in the manuscript. 
4. We deleted when possible some of Carrière's citations.

5. We deleted the mention to diameters because we used tree crown structure to elaborate the tree catego that we used to identify the population structure. We backed this approach with two new references.

6. We counted almost in an exhaustive way all trees of the three species we have considered and therefore this was not a sample. This is a descriptive approach of the status of what had been preserved in the two study sites. We have no comments therefore to make on sample size.

7. We added a short sentence on this subject. We consider that in the introduction part, we discussed what is known about these trends in Madagascar and have Added in that part more details about the failure of many NG projects. Our paper did not aim specifically to develop such elements that are contextual, not the subject of our research.

Other comments: 90: current decline in rule of law, rule of law is in fact slowly improving (compared to the post 2011 area: we have cited the Jones et al. 2019 paper which is the most recent and cannot assess the these trends of changes otherwise.

Regarding the Reviwer 2 propositions, we included almost all changes requested and are thankful for the help in refining the paper. 


\section{Full Title:}

2 Multiple values of isolated individuals of Ficus tree species protected by Betsileo farmers in

3 rural landscapes in Madagascar. Implications for biodiversity conservation

5 Short Title:

6 Multiple values of Ficus trees in rural landscapes, Madagascar

7

8 Authors:

9

\section{Affiliations:}

${ }^{1}$ Département de biologie et écologie végétales, Faculté des Sciences, Université d'Antananarivo, BP 906, 101 Antananarivo, Madagascar ; ${ }^{2}$ IRD-Montpellier, UMR Governance, Risk, Environment and Development (GRED), Université Paul-Valéry, Site St Charles, Route de Mende, F-34199 Montpellier cedex 5, France ; ${ }^{3}$ Centre d'Ecologie Fonctionnnelle et Evolutive, CNRS UMR5175, Univ. Montpellier, Univ. Paul Valéry Montpellier 3, EPHE, IRD, 1919, route de Mende, F-34293 Montpellier cedex 5, France

Corresponding author: Yildiz AUMEERUDDY-THOMAS : Centre d'Ecologie Fonctionnnelle et Evolutive, CNRS UMR5175, Univ. Montpellier, Univ. Paul Valéry 
21 Montpellier 3, EPHE, IRD, 1919, route de Mende, F-34293 Montpellier cedex 5, France,

22 yildiz.thomas@cefe.cnrs.fr. Tel +33643118153, ORCID iD : $\underline{0000-0002-2690-0571}$

23 Author details :

24 Title : Dr.

25 First name: Verohanitra M.

Last name: RAFIDISON

27 Academic degree(s): $\mathrm{PhD}$

28 Affiliation : Département de biologie et écologie végétales, Faculté des Sciences, Université 29 d'Antananarivo, BP 906, 101 Antananarivo, Madagascar

30 E-mail address : verohani@yahoo.fr

32 Title : Prof.

33 First name: Bakolimalala

Last name: RAKOUTH

35 Academic degree(s): PhD, Habilitation to Direct Research (HDR)

Affiliation : Département de biologie et écologie végétales, Faculté des Sciences,

37 Université d'Antananarivo, BP 906, 101 Antananarivo, Madagascar

E-mail address : ba.rakouth@yahoo.fr 
41 First name: Stéphanie M.

42 Last name: CARRIÈRE

43 Academic degree(s): PhD, Habilitation to Direct Research (HDR)

44 Affiliation : IRD-Montpellier, UMR Governance, Risk, Environment and Development

45 (GRED), Université Paul-Valéry, Site St Charles, Route de Mende, F-34199 Montpellier

46 cedex 5, France

47 E-mail address : stephanie.carriere@ird.fr

48

49 Title : Dr.

50 First name: Finn

Last name: KJELLBERG

52 Academic degree(s): PhD, Habilitation to Direct Research (HDR)

53 Affiliation : Centre d'Ecologie Fonctionnnelle et Evolutive, CNRS UMR5175, Univ.

54 Montpellier, Univ. Paul Valéry Montpellier 3, EPHE, IRD, 1919, route de Mende, F-34293

55 Montpellier cedex 5, France

56 E-mail address : finn.kjellberg@cefe.cnrs.fr

58 Title : Dr

59 First name: Yildiz

60 Last name: AUMEERUDDY-THOMAS 
61 Academic degree(s): PhD, Habilitation to Direct Research (HDR)

62 Affiliation : Centre d'Ecologie Fonctionnnelle et Evolutive, CNRS UMR5175, Univ.

63 Montpellier, Univ. Paul Valéry Montpellier 3, EPHE, IRD, 1919, route de Mende, F-34293

64 Montpellier cedex 5, France

65 E-mail address : yildiz.thomas@aumeeruddy-cefe.cnrs.fr

66

ORCID iD : $\underline{0000-0002-2690-0571}$

67

Phone : +33643118153

68

69

70

71

72

73

74

75

76

77

78

79 
INTRODUCTION

Madagascar is widely recognized for the high rate of endemism and the richness of its biodiversity (Goodman and Benstead 2003; Ganzhorn et al. 2014). Most of the population of Madagascar (80\%) lives in rural areas, conducting agriculture and pastoralism, and relies on biodiversity for food, medicine, fuelwood, and timber (Waeber et al. 2015). Increasing threats to Madagascar's biodiversity critically affect the integrity of ecosystems, inside protected areas and in rural landscapes, affecting local livelihoods (Jones et al. 2019). Agriculture, charcoal production and zebu grazing in forest areas by local inhabitants have driven deforestation, resulting in loss of habitats and biodiversity (Waeber et al. 2015). However, corruption associated with new agribusiness and mining activities brings new threats from forces acting at national and global scales. The current decline in the rule of law in Madagascar could greatly harm biodiversity and local livelihoods (Jones et al. 2019).

In this paper, nature is used following the concept of Nature's Contributions to People (NCP) defined by Diaz et al (2018) whereby nature relates to living nature, i.e., the diversity of organisms and the ecological and evolutionary processes within ecosystems. "Nature" can have different cultural meanings for different societies. In this paper, we consider this living part of nature as equivalent to biodiversity.

In Madagascar, people are connected to the power of life and nature known as Hasina, through the mediation of ancestors, their burial places and particular species or elements of ecosystems (Harper 2003, Aumeeruddy-Thomas et al. 2018). Access to different parts of territories and resources follows specific rules and management practices framed upon reciprocity between people and elements of biodiversity (Diver et al. 2019). Within this context, some species, groups of species, or ecosystems such as portions of forests are seen as active agents that may interact with people or elements that participate in the identity of people. Indeed, from the perspective of some Malagasy groups, forests reflect not only natural 
history, but social history. They are viewed as symbols of shared histories of collective empowerment, including resistance to outside control (Harper 2003). Social organization governing access to different types of elements of nature in Madagascar is based on social hierarchies and systems of power that have built up along history. In particular, the Merina ${ }^{1}$ king Andrianampoinimerina ((1787-1810), united Malagasy groups (e.g. Sakalava, Betsileo, Betsimisaraka and many others that previously were organized in the form of small independant kingdoms) to establish a state at the beginning of the $19^{\text {th }}$ century. enforced a caste system including andriana (noble), hova (free) or andevo (slave). This system served the interests of the king's taxation system based on a reinforced link to the land and tombs that also facilitated the control of allegiance by all social groups to the Merina. The andriana status could be conferred for loyalty or service to the king, while hova took on varied meanings in different parts of the island but in all cases referred to people possessing lands and ancestors buried in these lands.

Some Ficus species, such as Ficus lutea, are among these particular species that symbolized the power of the king Andrianampoinimerina and contributed to enforce his hegemony (Aumeeruddy-Thomas et al. 2018).

In the Highands, the organization of landscapes is defined by diverse categories of spaces, which each bear a local term that designates jointly ecological aspects and associated practices (Blanc-Pamard 1986, Blanc-Pamard and Rakoto Ramiarantsoa 2007). Formal and informal social hierarchies, local institutions and practices (including rituals, such as zebu sacrifices in the case of Madagascar) and exchange networks define people's relationships within social-ecological systems (Berkes and Folke, 1998). Such complexity is rarely taken into account in conservation policies in Madagascar, which are historically based on zonation

\footnotetext{
${ }^{1}$ The Merina is the dominant cultural group that livesin the northern part of the Highlands in Antananarivo and in the surroundings of what came to be the capital city of the country.
} 
and restricted access shaped solely by biological considerations Marie et al. 2009, Diver et al. 2019).

Indeed, conservation policies in Madagascar are based on protected areas from which people are excluded. These policies, initiated by the French colonial government, have continued to the present, with investment from numerous international conservation NGOs. The network of protected areas was expanded in 2003. Additions included the establishment of ecological corridors such as the Ambositra-Vondrozo forest strip connecting Ranomafana and Andringitra National Parks that was created in 2008. This corridor, which borders our study area, acquired an official status as a "New Protected Area" with restricted access (Blanc-Pamard and Rakoto Ramiarantsoa 2007; Rakoto et al. 2014).

As in the rest of the world, since the 1970's there have been many efforts in Madagascar to develop approaches that integrate biological conservation and human development (Marie et al. 2009; Aumeeruddy-Thomas 2013). Numerous efforts were made in Madagascar by a large diversity of NGOs to integrate human development into conservation. However, it seems that the urgency for developing the conservation network, led by the global conservation agenda and its priorities, accorded little attention to local knowledge, practices and institutions including attachment to land (Marie et al. 2009). Globally, results of similar efforts elsewhere have generally been unsatisfactory (Ward et al. 2018). In Madagascar, GELOSE, a national law adopted in 1996, aimed to devolve the management and conservation of forests to local communities and stimulate economic development. Contractual agreements between the state and local community-based groups $(\mathrm{CoBa})$ were drawn up, defining rules of access in a zonation system based mainly on conservation priorities. Social scientists pointed out that GELOSE redefined access to spaces in a way that did not take into account practices of the area's rural population (Blanc-Pamard and Fauroux 2004). McConnell and Sweeney (2005) further explain: The policies "reify monolithic communities to which authority can be rapidly 
devolved, when in fact these 'local communities' are difficult to define, much less successfully engage in conservation activities, especially after a long era of strong state control". These experiences highlight the gap between global conservation endeavors and local socialecological dynamics.

At the global level, new approaches take into account the importance and role of biodiversity outside protected areas, and address landscape and social dynamics (Mora et. al. 2011). New types of conservation areas include IUCN categories V and VI, UNESCO Intangible Heritage sites, FAO Global International Agricultural Heritage Sites, and other types known as "other effective area-based conservation measures" or "OECM" (https://www.iucn.org/commissions/world-commission-protected-areas/our-work/oecms) among which different types of governance are recognized including by governments, private actors, indigenous peoples and local communities, and areas of shared governance. Maintaining extensive anthropic landscapes featuring a mosaic of low-input agriculture has been characterized as a "land-sharing" strategy that conserves biodiversity while sustaining agricultural production (Perfecto and Vandermeer 2010). Such landscapes are often significant reservoirs of biodiversity (Kun et al. 2009; Kull et al. 2013). This biodiversity may be critical to ensure the resilience of ecosystem functions, particularly in the present context of rapid climate change (Manning et al. 2019, Renard \& Tilman 2019).

Tees or clusters of trees (e.g. small woods, hedges) initially part of forest environments, or those planted as isolated trees or within clusters of trees, can help create or re-establish connectivity in fragmented a agrarian landscapes. They offer resources to animals and accelerate plant successions (Carrière 2002; Manning et al. 2006; Eden et al. 2015). Species of Ficus (Moraceae) are particularly important in this regard. Trees of this pantropical genus, which numbers about 800 species, are hubs in vast webs of interactions. These include the specialized insect pollinators, parasites and parasitoids of Ficus. They also include mammals 
and birds that eat fruits and disperse seeds not only of Ficus but also many other plants (Shanahan et al. 2001; Harrison and Shanahan 2005; Kjellberg et al. 2005). When Ficus grow as isolated trees, they act as stepping-stones for forest animals in open habitats (Martin et al. 2009). They also function as nuclei accelerating plant succession, as the frugivorous animals that visit them disperse seeds of forest plants in their droppings. These seeds germinate and establish, forming small patches of vegetation around these focal trees (Carrière 2002). I Madagascar and elsewhere, Ficus trees are also associated with multiple social values that connect people to territories and nature (William and William 2013, Eden et al. 2015; Rafidison et al. 2016; Aumeeruddy-Thomas et al. 2017, 2018). Madagascar has 25 native Ficus species belonging to four subgenera, of which 15 species are endemic and four are shared with the African continent (Dalecky et al. 2003; Rafidison et al. 2011). Taxonomic and ecological information on Ficus species of Madagascar is given in Table 1. Three Ficus species represent $33 \%$ of the isolated trees (sample size 45) in Betsileo rural landscapes; they attract numerous bird species as well as bats (Martin et al. 2009). Some species, such as F. tiliifolia, are highly attractive to frugivorous animals (Goodman and Ganzhorn 1997). Ficus have a cultural value for the Betsileo, and are protected for this reason, but a full understanding of their multiple values and their contributions to social-ecological dynamics is still lacking (Moreau 2002; Martin et al. 2009).

\section{OBJECTIVE}

Our objective is to understand social-ecological dynamics that affect the distribution, uses and values at the landscape level of Ficus species that are protected by Betsileo communities in two rural landscapes. We use our findings to discuss the importance of collaborative approaches that consider local social-ecological dynamics that can improve biodiversity management and human livelihoods. 
We focus on farmers' local knowledge and historical, cultural and practical reasons that explain why farmers plant and/or protect Ficus trees in their agrarian landscape. We use an ethnobotanical approach to assess the uses, multiple values and distribution of Ficus spp. within the territories of two Betsileo villages that border the Ambositra-Vondrozo forested corridor. Our specific aims are to:

(1) Identify the relationships between their distributions and uses, within the history o the construction of their rural landscape by the Betsileo in two sites;

(2) Identify past and present socio-political, economic, practical and symbolic values attributed to Ficus species by two Betsileo communities and consequences of these values for their management;

(3) Propose rules of thumb for designing collaborative approaches based on our understanding of local social-ecological systems and the roles of key elements such as Ficus species.

\section{STUDY SITE, MATERIALS AND METHODS}

Our study area is located on the eastern side of the Malagasy Highlands. It is bounded to the west by a mountain ridge that stretches north to south along Madagascar. A forest strip known as the Ambositra-Vondrozo corridor, characterized by a dense mid-altitude humid forest (Goodman \& Razafidratsita 2001), covers the portion of forest adjoining our study area and joins Ranomafana and Andringitra National Parks. Tanala people, who are distinct from the Betsileo, inhabit the humid eastern slopes of this escarpment.

Betsileo cultural groups inhabit our study area, which is characterized by rugged relief comprising hills, slopes, valleys and flat marshy areas. Farms comprise hill and downslope marshy lands, the latter often exploited for paddy rice cultivation. Irrigated terraced lands are 
also used for paddy rice. Slopes are used to grow rain-fed maize, cassava and beans. Permanent agriculture has replaced swidden agriculture (tavy), which may still occur on forest fringes. To the east, the rural landscape is a mosaic of secondary forest of varying age resulting from past swidden cultivation, intermingled with sedentarized paddy rice and upland cultivated areas. To the west, the agricultural landscape becomes increasingly open, with plantations of eucalyptus or pine found only on hilltops. Lying in continuity with the Malagasy Highlands, this rural landscape is bounded on the west by a series of high cliffs (Fig 1). The climate is tropical with a dry season (April - September) and a rainy season (November - March); altitude varies between 1100 and $1300 \mathrm{~m}$ a.s.l.

The mosaic of cultivated and non-cultivated habitats, including fragments of native forest, plantations of non-native species (e.g. Eucalyptus), hamlets and villages is highly heterogeneous, thus favoring some types of biodiversity associated with anthropogenic rural landscapes (Kull et al. 2013).

We investigated the territories, comprising customary agrarian and forest lands, of two distinct Betsileo villages, Ambendrana (Site 1; Lalangina district, Fokontany (municipality) Iambara) and Sahabe (Site 2; Ambalavao district, Fokontany (municipality) Andohanimananatanana), separated by approximately 60 km (Fig 1).

Previous works in human geography (Moreau 2002; Blanc-Pamard and Rakoto Ramiarantsoa 2007) and in ecology and ethnobotany (e.g. Carriere et al. 2005; Martin et al. 2009) in these sites provide context for our work. Further context is provided by studies of distribution patterns of Ficus species in the forest corridor and the two national parks (Kjellberg et al 2010, Rafidison et al. 2011). Choice of these two sites for this study allowed investigating how social values accorded to Ficus species interact with their ecology. 
Our two study sites belonged historically to distinct Betsileo chiefdoms until the unification of the country by the Merina in the $19^{\text {th }}$ century. The Betsileo cultural group the largest cultural group that inhabit the southern part of the Highlands (Harper 2003). The Betsileo originate from an admixture of groups of migrants who successively colonized the highlands. Their language includes linguistic elements of different cultural groups (Antemorro, Tanala, Merina) (Dubois 1938). They transformed the forest with swidden agriculture (tavy), cultivating mostly rainfed rice (Dubois 1938). The advent of irrigated rice cultivation among the Betsileo during the late $17^{\text {th }}$ and early 18 th centuries has been attributed to internal changes associated with a demographic increase, participation in trade of slaves and weapons, and contacts with the Merina (Kottak 1977). The Betsileo were comprised of distinct small chiefdoms, each with its specific frontiers, territories and hierarchical system (Kottak 1977; Raherisoanjato 1984). Ambendrana (Site 1) was part of the Lalangina chiefdom (Kottak 1977), and Sahabe (Site 2) belonged to the Arindrano chiefdom (Giambrone 1973; Kottak 1977). After unifying the country during the $19^{\text {th }}$ century, the Merina reinforced drainage and irrigation to favor paddy rice cultivation and collected taxes. The French colonial government ruled Madagascar from 1896 to 1960.

Details on Ficus species found in the study area (Table 1) show aspects of their ecology, their life forms, fruit size and geographical distribution. We analyzed the uses and values of all the nine Ficus species found in our sites, and looked in detail only at the distribution of the three most common species, Ficus lutea, F. reflexa and F. tiliifolia. These species are found mainly in eastern and southeastern Madagascar at altitudes below $1700 \mathrm{~m}$ (Dalecky et al. 2003; Rafidison et al. 2011).

We conducted ethnobotanical studies during successive periods of 15 days totaling six months in the two sites. Open-ended interviews were conducted with 64 (Ambendrana) and 90 persons (Sahabe), children, adults and elders of both sexes from farmer families (Table 2). 
Among all persons interviewed, the elders ray aman-dreny, (literally "father and mother" representing customary heads), and ombiasy (traditional healers), and lineage heads (adults or elders), had extensive knowledge of local history and social practices. Local ombiasy use Ficus species, among other plants, to mediate, through dreams and visions, interactions between humans, ancestors and intangible entities of nature (Beaujard 2009). Lineage heads and elders accompanied us to locate Ficus individuals and provided ethno-historical information on present-day practices and oral memory of past uses and practices. We recorded local names, sayings and stories relating to plants and places. All interviews were in Betsileo and were transcribed literally. Following the terms of our research permit (No $\left.{ }^{\circ}: 193 / 08 / \mathrm{MEFT} / \mathrm{SG} / \mathrm{DGEF} / \mathrm{DSAP} / \mathrm{SSE}-01 / 07 / 08\right)$, all informants were informed that their responses would be used for scientific purposes and all gave their consent. Heads of these villages and major informants were invited to Antananarivo in 2016 and contributed as authors to a paper presenting preliminary results (Rafidison et al. 2016).

We determined the distribution of individuals of the three most common Ficus species across the two rural landscapes according to their position relative to distinct land-use units distinguished by local people. Land-use units were defined as social-ecological facets, building on the concept of ecological facet used by Blanc-Pamard (1986). We define a social-ecological facet as a locally recognized spatial entity characterized by homogeneous ecological and use characteristics. All social-ecological facets are designated by distinctive names in Betsileo. These names are interpreted locally to represent types of land associated with a particular set of practices. They include land-use units as well as elements such as tombs, megaliths, rivers, rivulets and paths that are markers of agrarian and forest territories (Table 3). We complemented the list of facets recorded by Blanc-Pamard and Ralaivita (2004) in Ambendrana and identified those of Sahabe. 

hills, each generally associated with one farm (18 in Ambendrana and 13 in Sahabe), was recorded with the help of owners of the land and other inhabitants. They provided ethnobotanical data during field surveys on all Ficus species. We identified all Ficus individuals to the species level and characterized the social-ecological facets in which the three most common species occurred and noted GPS coordinates. All elements of the landscape, such as houses, planted or spontaneous vegetation, rivers and cliffs were noted, and schematic drawings were made in order to obtain a visual record of the spatial relationships between the different elements of the rural landscape. An example of these schematic drawings is given in Fig 2 . Almost all Ficus individuals of the most common species found in the territories of the two inaccessible areas such as cliffs. For example, for Ficus reflexa, all individuals planted around zebu corrals were counted. Similar exhaustive censuses were conducted on all three most common Ficus species.

We aimed at understanding population dynamics of $F$ tiliifolia (the only species out of the three chosen for a detailed study that was not planted or very rarely), to identify whether this species could maintain itself without human interventions. We classified F. tiliifolia individuals into three categories on the basis of their architecture, following Hallé et al. (1978), and functional categories of 'trees of the past' or old (trees with complex branching patterns, large round to flat crowns), 'trees of the present' or mature (trees with simple branching patterns and a pyramidal crown) and trees of the future or young (saplings with few lateral branches) (Oldeman and van Rijk 1991). These functional categories are supported by studies on tree architecture that consider repetitions and reiterations as elements of trees' ontologies 
(Barthélémy and Caraglio 2007). Furthermore, we cross checked the trees' relative age with the help of elders' local expert knowledge.

\section{RESULTS}

We conducted ethnobotanical surveys of uses and practices related to the nine Ficus species found in these two sites with 154 informants. Distribution patterns were documented in detail for the three most abundant species. In the two sites, we recorded a total of 195 isolated trees of Ficus tiliifolia, 138 individuals of Ficus reflexa, isolated or in clusters in small woods or liv hedges located around zebu corrals, and 29 individuals of Ficus lutea, isolated or mixed with F. reflexa around zebu corrals.

\section{Naming and symbolic and material uses of Ficus species}

All Ficus species are known locally, bear names shared by all inhabitants and have one or several associated symbolic and material uses; sets of uses differ among species (Table 4).

\section{Naming}

Names are symbols generally linked to significant meanings that are linked either to a characteristic (motivated) or are arbitrary (non-motivated). All nine Ficus species bear motivated names. The Betsileo have no generic taxon name that corresponds to the genus Ficus. But once people realized our interest for Ficus species, they showed without hesitation all Ficus species growing in their territory and only Ficus, even those we did not know initially. Some names are based on a system of correspondence or analogy with the human body and other names refer to the social significance accorded to the tree, its morphology, the type of fruits it bears, the uses of its leaves and potentially the tree's links to other cultural groups, especially the Merina.

Each species bears a distinct motivated name except for two pairs of species that bear each the same motivated name ( $F$. politoria and F. brachyclada; F. botryoides and F. trichoclada). 
The first two, like many species of the section Sycidium, have scabrous leaves that can be used as sandpaper and are named kivozo or ampaly (literally, "scabrous"). The second pair, named fompoha, have young tree stages that are similar morphologically and are closely related species in section Sycomorus. Fompoha (literally "to blow") relates to the small cloud of tiny insects that come out of the ostiole (opening at the apex of all figs, through which fig wasps penetrate to pollinate the flowers inside, and through which their offspring emerge when the fruit matures) when one blows on a mature fig. Children readily demonstrated to us how they blow on F. botryoides fruits to make the fruit more palatable.

The name amonta (literally, "abundance") is given to Ficus lutea, because it is associated with noble Betsileo classes (hova). Seedlings are protected for this reason. "Avelao hitsiry ny amonta dia ny taranaka sy ny harena mba hamontafonta" (Leaving the seedling of amonta to grow will make local descendants also rich). Although seedlings are allowed to establish anywhere, poor people are forbidden from planting this tree near their houses.

The name nonoka, applied to $F$. reflexa, means a feeding breast or the act of sucking milk (Table 4). The abundant white latex produced when the tree is wounded is associated with human milk and by analogy, leaves are used by breast-feeding women to increase milk production.

Voara (F. tiliifolia), (literally "fruit of ara", the term ara meaning literally, "what is linked to" presumably to all people) is said to be the "reninkazo" (literally mother tree) and is a symbol of fecundity. People relate this name to the tree's height and its abundant fruits, appreciated by children and zebus, its uses for making clothes and as a medicine for women giving birth. Voara is perceived as a tree that attracts and maintains water in the soil. By analogy, cutting a voara is a negative act that may lead to the drying up of children's tears or of a mother's milk. Two varieties of Voara are named according to the distinctive traits of their fruits, such as sweetness (Voaramalefaka) or an atypical shape of the fruit (Voarabekobo, meaning "with a thick lip"). 
Ficus trichopoda is named aviavy meaning in Betsileo "arriving", the same name is used by the Merina for Ficus polita in Antananarivo. Tsaramady, used by the Betsileo for F. polita, means literally "the good one".

\section{Uses}

Uses of fig trees may vary according to the socio-ecological facets in which they grow. These uses, both symbolic and material, are dependent on whether the trees grow naturally or have been planted. Meanings and roles of the different Ficus species also vary depending on their historical connections with the Betsileo. For instance, the social significance of F. tiliifolia is strongly influenced by the past use of its bark as a textile, a use that was renewed during the turmoil of the 1940s for making blankets or coats which had a high economic value; a coat could be exchanged for a zebu. Ficus also figure in representations of political relationships of the Betsileo with other cultural groups in Madagascar. For example, a little ditty of the Merina is known by the Betsileo : "Isa ny amontana, roa, ni aviavy, telo fangady" (literally: "one is amontana king, two is aviavy and three is the Malagasy spade") which was diffused in Madagascar by the Merina as a device for children to learn to count. Amontana (F. lutea), an $\operatorname{aviavy}(F$. polita) symbolize the Merina kings' residential areas and power. The name Amonta is used by Betsileo, but it is only planted by hova (nobles) who presumably have paid allegiance to the Merina. Aviavy is used by the Betsileo to name F. trichopoda.

\section{Material and symbolic medicinal uses}

All Ficus species have medicinal uses for the Betsileo and all are used today to treat diverse diseases (diarrhea, cough, fever, worm infections) and to treat wounds and a range of complaints related to women's health. Some uses are shared between two or more species. The latex of F. lutea, F. tiliifolia and F. reflexa is used to heal wounds. Healing practices used by ombiasy (healers) make use of all Ficus species found in the area. Ancestors' spirits, called 
upon by the ombiasy, are said to systematically designate Ficus products as important remedies. The ombiasy receive this information through dreams or during possession rituals.

\section{Other material and symbolic uses}

All Ficus species have technical uses that confer to them an economic value. Some species are widely recognized by the Betsileo to be consumed by animals such as birds, bats and lemurs, but some are known to be particularly attractive $(F$. reflexa and $F$. lutea). This knowledge is used when Betsileo hunt bats. The latex of F. reflexa and F. trichopoda is used as birdlime.

Fruits of $F$. tiliifolia, F. lutea, $F$. reflexa and $F$. botryoides are eaten by people, mainly by children. The fruits of $F$. tiliifolia were traded before new fruit species were introduced into the area.

The bark of both $F$. politoria and $F$. pachyclada is used for making strings and ropes, while the bark of $F$. tiliifolia and $F$. botryoides was used for making textiles and is symbolically associated with past lives of ancestors. Other technical uses are numerous, including planting of stem cuttings to prevent erosion through making living hedges ( $F$. reflexa and $F$. botryoides) and use of dry leaves as fertilizer (F. tiliifolia) (Table 4). All these species are used as land markers but the species most frequently used for marking ancestors' tombs are $F$. reflexa and F. lutea.

\section{Tree management practices: an ethnohistorical construction of Betsileo landscapes}

All Ficus species have symbolic and material uses that together determine when and where they will be protected or not. Symbolic uses of a given species can vary depending on the social-ecological facets in which individual trees grow. Indeed, any Ficus tree that grows from self-sown seedlings near social-ecological facets such as tombs, steles, abandoned ancient villages or elements of landscapes such as large rocks, are systematically protected. Indeed, their seeds are perceived to have been brought into these places by ancestors or other intangible 
creatures. Fig trees are therefore a cultural element of the landscape and not solely an element of natural regeneration.

When growing in the middle of a field, where they may hinder agricultural production, spontaneously establishing fig trees of all species can be cut, despite a number of sayings and beliefs that encourage their protection. There is no strict fady (taboo) that protects Ficus species from being destroyed. Ombiasy also indicate to local inhabitants how to plant particular Ficus species. The ombiasy empower the tree through magical practices by adding a charm to trees planted on the border of zebu corrals to protect the latter against evil spirits or robbery, a practice named "tafotombala" (literally: "that brings wealth").

\section{Reading the landscape: ethno-historical indicators}

Records of oral memory of the Betsileo, together with their local knowledge of landscape elements, show that their indicators of the composition of their rural landscapes are socialecological facets, encompassing material (e.g., ecological and topographic aspects, types of agricultural practices or human habitats) and symbolic aspects (e.g. burial places, other markers of the memory of ancestors). Naming of social-ecological facets is precise (Table 3). They can be grouped into five large categories: vegetation types, agricultural land-use types, topographical elements, extraordinary or specific abiotic facets, and historical and sacred facets.

Based on these indicators, we identified three overlapping ethno-historical zones along an east-west axis in site 1-Ambedrana (Zone A-eastern forest; zone B-protected hill-tops; Zone C15 roofs area) (Fig 3). The "15 roofs period" refers to the period, during the $19^{\text {th }}$ century, when Merina administrators developed larger villages for the Betsileo, associated with markets closer to the lowlands. In Zone C-15 roofs area, the landscape is shaped both by activities conducted before the unification of Madagascar by the Merina and those developed with the establishment of a new village center during the Merina period, and contemporary periods. Details of the 
landscape composition including traces of past activities, vegetation types, agricultural practices and Ficus distribution are given in the online resources (Online resource 1).

In Sahabe, pasture lands occupy larger areas than in Ambendrana; forest remnants are few and pasture and cultivated lands form the major part of the rural landscape. Small areas of forest fallows, associated with past tavy practices, are still found within Sahabe's open rural landscape. We characterized the rural landscape in Sahabe as a Zone C-15 roofs area for the purpose of comparison with a similar ethnohistorical area in Ambendrana. No east-west axis is visible, in contrast to Ambendrana (Fig 4). We do not have an explanation for the absence of a Zone B-protected hilltop in this site. We visited areas near forest fringes where none of the three Ficus species most common in our two sites were found.

\section{Management practices and distribution patterns of Ficus trees}

Two groups of Ficus species can be differentiated according to how individuals establish within the rural landscape. Species of the first group regenerate exclusively through self-sown seedlings (F. tiliifolia, F. politoria and F. brachyclada). Species of the second group reproduce by seedlings but are also actively propagated by large pole-like cuttings (F. reflexa, F. lutea, $F$. botryoides, F. trichoclada, F. polita and F. trichopoda). We recorded in situ only individuals of $F$. trichopoda that were propagated by cuttings (six individuals in site 1 and site 2 in Zone C-15 roofs area far from the forest), but local experts explain that seedlings exist, are rare and are protected (Table 2). Ficus trichopoda is found growing in the forest only on the eastern side of the mountain ridge.

\section{Regeneration only by seeds: example of F. tiliifolia}

Ficus tiliifolia is abundant (70 individuals) in Zone A-eastern forest in Ambedrana but absent in Sahabe. In Zone B-protected hill-tops (this zone is inexistent in Sahabe), F. tiliifolia is less abundant (21 individuals) in Ambendrana than in Zone C-15 roofs area, with 65 individuals in Ambendrana and 39 in Sahabe. 

social-ecological facets, marking transitions between two types of landscape elements. Such positions are occupied by $57 \%$ of 70 individuals in Zone A-eastern forest, $81 \%$ of 21 individuals in Zone B-protected hill-tops, and $59 \%$ of 65 individuals in Zone C-15-roofs area In Sahabe, individuals located between two social-ecological facets, in Zone C-15 roofs area represent $41 \%$ of 39 individuals and are totally absent near the eastern forest fringes (Online resource 2).

The abundance of F. tiliifolia between two social-ecological facets indicates that they have been cut within each facet, e.g., during tavy clearing activities. The photo shown in Fig 5 portrays an individual originating from the forest that has persisted on the edge of a paddy field. Such trees were incorporated into agricultural lands progressively as fields became permanent. According to local knowledge, all Ficus tiliifolia found across the landscape were trees maintained mostly by forefathers due to their multiple values. F. tiliifolia very rarely regenerates now in agricultural lands. It is still generally protected as a part of the heritage but in some cases, when the tree affects crop productions, individual tree may be cut. It is otherwise maintained for its qualities for fertilizing soils and for maintaining soil water, when it does not hinder agricultural production (Table 4). Analysis of the population structure of $F$. tiliifolia in the two study sites shows that old trees are predominant (91\%) with only one individual representing the young stages (Fig 6).

Ficus species that both regenerate by seeds and are propagated by stem cuttings:

\section{examples of Ficus reflexa and Ficus lutea}

Ficus reflexa is rare in Zone A- eastern forest areas in both Ambendrana (three individuals) and in forest fringes of Sahabe (five individuals). In Zone B- protected hilltops, $F$ reflexa is absent in Ambendrana. It is most abundant in site C-15 roofs area in both sites, with 44 individuals in Ambendrana and 89 in Sahabe. 

facets (71\% of 44 individuals at Ambendrana; $93 \%$ of all individuals at Sahabe). They are associated with vatobe (steles) and vatolahy (very large ancient megaliths), fasana (sacred woods), alagasy (forest), and tanimboakazo (orchards), places where they establish as seedlings and are then protected. Valanomby (zebu corrals), tananahaolo (abandoned villages), cour (courtyards), and valamparihy (mud walls along rice fields) are typically facets where individuals of this species are planted as pole cuttings. Some individuals are associated with tombs, thickets, pasturelands and threshing areas or grow spontaneously as hemiepiphytes on old forest trees bordering fields or as lithophytes on rocks (Online resource 3) Ficus lutea is rare in Ambendrana (five individuals) and found only in zone C-15 roofs area. Several plants from self-sown seedlings were found nearby on the cliffs (not counted). In Sahabe, this species is more abundant (24 individuals). In this site, most individuals are located at edges between two social-ecological facets (71\% of 24 individuals). They grow from spontaneous seedlings, which are always protected. They are also planted by large stem cuttings, but only members of noble classes are allowed to plant them, never ordinary people. They are absent in Zone A-eastern forest and Zone B-hill tops. Some individuals are also found on the humid eastern slopes (Tanala side) of the mountain ridge (V. Rafidison \& F. Kjellberg, unpublished data) (Online Resource 4).

According to local knowledge in both sites, plants of $F$. lutea growing in Zone C-15 roofs area originate from seeds brought by birds and bats that visit the cliffs or orchards. Individuals found in abandoned villages (tanana haola) in courtyards of noble people or rayamandr en and in old herbaceous fallows (songonala), originate from the plantating of large stem cuttings. According to ethno-historical accounts, they were planted by noble Betsileo classes, as a symbol of their power over land and a sign of their connection to the Merina kingdom. Individuals growing spontaneously on tombs are strictly protected. Some individuals are found 
regenerating naturally at the foot of the cliffs both in Ambendrana (few) and Sahabe (numerous, not counted).

\section{DISCUSSION}

Of the 24 Ficus species identified in the forest corridor that joins Ranomafana and Andringitra National Park (Rafidison et al 2015), nine are present and protected as isolated trees or as clusters in liv dges or in small woods in the adjoining rural landscapes of Ambendrana and Sahabe. Martin et al. (2009), show that $33 \%$ of isolated individuals (sample size, 48) of tree species are represented by three Ficus species (F lutea, tiliifolia and trichopoda).

The protection of the nine Ficus species is driven by their multiple uses and varies depending on their distribution in social-ecological facets. Ethnohistorical accounts show temporal continuity of some of the practices associated with these species, and also document changes over time. Distinct sets of uses (past, present, symbolic and material), are associated with each species. Multiple relational, economic and ecological values link uses and the distribution of Ficus trees in the landscape following social-ecological dynamics. Distribution patterns of the three species show that they are predominantly protected as "frontier" elements between social-ecological facets. Local people explain the greater numbers of these trees at the edges of agricultural lands by the fact that they are cut within agricultural areas when they hinder production, but are left in other places to fertilize soil and maintain soil water supply. Our analysis of the protection of Ficus trees also shows links between symbolic, material and economic dimensions. For example, when found near zebu corrals, Ficus trees play symbolic roles through charms to protect zebus and humans, but also have an important role in preventing soil erosion, thereby maintaining the sunken basins cut into the soil that serve as zebu corrals. No strict taboo $(f a d y)$ enforces their protection, but some sayings encourage people to protect them. However, a fady or strict rule forbids the active plantation of Ficus lutea and F. 
trichopoda, especially by ordinary people, although plants of these species that originate from self-sown seeds can be protected. Plants that establish naturally from seeds are considered by local people to have been planted by ancestors and other intangible creatures, and are highly valued, especially when they grow in social-ecological facets such as burial areas, steles or other landscape features such as rocks and cliffs. Out of the nine species, seven are actively planted by stem cuttings (Table 4) following decisions about where they should be planted and choice of social-ecological facet(s). Regarding the species that regenerate exclusively by seedlings (rare), their degree of protection remains unclear because they are rare.

\section{Vernacular and scientific taxonomy}

Our results show that identification and a comprehensive naming system of Ficus species is shared by all inhabitants from elders to children in both sites. This enhances the capacity of the Betsileo as a cultural group to share knowledge and rules pertaining to management practices, a mechanism known from many traditional societies (e.g. Friedberg 1986, Ellen 1996). How Betsileo identify Ficus species and how scientists identify them are quite similar. Although they do not use a generic category encompassing all Ficus, the Betsileo identify Ficus species by observing similarities and differences among them in morphological and other traits of leaves, fruits, bark and latex. Differences in growth habits, such as those between hemiepiphytes or lithophytes (able to germinate and grow on rocks) and those that grow only as standing trees, are also considered. Aspects of their phenology, such as the asynchronous production of leaves of some Ficus species, are also taken into account. The traits used to identify different species are often those associated with the uses of each species. For instance, the two species found locally whose leaves are scabrous are both named ampaly, meaning scabrous (Table 4), and are among the few pairs of species that bear the same name. They are in fact sister species in the section Sycidium of the genus (Table 1, 4). 

species all belong to the section Sycomorus of the genus (Table 1). The large and conspicuous crops of figs produced by these species are well-known by scientists to attract mammals

570 (Shanahan et al. 2001; Harrison and Shanahan 2005). Fruits of many species of section Sycomorus are widely eaten by humans, for example in Africa (Burrows and Burrows 2003). Ficus botryoides and F. trichoclada bear the same local name (fompoha) and share the same uses, and indeed are sister species in the phylogeny of Ficus. Both are cauliflorous (bearing fruits on the trunk). Both grow in riverine forests and have very similar leaves (F. Kjellberg, unpublished data). Ficus sycomorus, the type species of section Sycomorus, which produces prolific amounts of fruits, is protected and its fruits are eaten near Tulear in western Madagascar (V. Rafidison, unpublished data). This species is widely utilized throughout Africa for its fruits, including in Egypt, beyond its natural distribution area, where it was domesticated by the ancient Egyptians (Burrows and Burrows 2003).

Other Ficus whose fruits are eaten are F. lutea, F. trichopoda, F. polita and F. reflexa. These species belong to section Galoglychia. The fruits of the first three species are consumed by humans because of their large size. In the area of Antananarivo, for example, the unripe fruits of $F$. polita are traded and consumed for their well-known benefits for the throat (Aumeeruddy-Thomas et al 2018).

A most fascinating characteristic of species of section Galoglychia is their hemi-epiphytic and hemi-epilithic growth form. This characteristic, associated by the Betsileo with the idea that the seeds are "planted" by intangible creatures, is the reason why people protect them especially on sacred social-ecological facets, such as rocky steles or megaliths, and in small isolated woodland patches (songonata) within the open landscape. These woodland patches derive from nucleation processes as explained above (Martin et al. 2009; Rafidison, 2013). Such vegetation dynamics are also known for 'orphan' trees protected in swidden agriculture in 
Africa (Carrière 2002) and in Asia (Eden et al. 2015). These small woods within open Betsileo landscapes acquire a sacred value, being associated with tombs or steles and Ficus species.

Most of the uses of Ficus documented in the Betsileo sites, such as their use to improve milk production by breast-feeding women, or by cattle, or their use as live hedges for protecting people or cattle, are similar to those of the same species elsewhere in Madagascar or of other Ficus species in Africa (e.g. Burrows \& Burrows 2003), Asia (Kunwari and Bussman 2006) and the Pacific (Walter and Sam 1999).

\section{Continuities between past and present uses, symbolic and material}

Continuity between past and present-day uses is a key driver of the protection of isolated Ficus trees, or clusters of them, found in Betsileo rural landscapes. Human memory associated with transmission of local knowledge by forefathers, and ways people view this transmission as part of their identity, are key to linking people to biodiversity (including agrobiodiversity), places and landscapes (Nazarea 1999). Roles of trees in building territories and relationships to nature have been highlighted in many societies. Their perennial dimensions, multiple economic uses, and perceived symbolic analogies linking humans to trees are characteristics that favor their presence in many local territories. Their protection is further enhanced by diverse beliefs in their roles as mediators, or as hosts of intangible entities that may have positive or negative impacts on human well-being (Aumeeruddy and Bakels 1993; Rival 1998; AumeeruddyThomas et al. 2018).

Trees, in this case Ficus species as perennial species, are transgenerational markers of local social-ecological systems and landscapes and link the present to cultural memory. Their role in the memory of the Betsileo can be compared to that of other permanent features such as topographic elements (hills, mountains, cliffs or rocks). Links between their symbolic and practical uses and the trees' ecology, their spontaneous regeneration by seeds in specific 
habitats, or their propagation by stem cuttings, are jointly used for their management, as shown also for F. carica in the Mediterranean region (Aumeeruddy-Thomas and Hmimsa 2019).

Isolated or clustered individuals of Ficus within open agricultural landscapes participate in the construction of these rural landscapes, as markers of local history and as testimony to local attachment to the land and its resources. This attachment contributes to reinforcing local governance of social-ecological systems. During times of turmoil faced at the national level when threats on biodiversity, agroecosystems and local livelihoods are increasing, looking at ways local knowledge is linked to remarkable trees from cultural, economic and ecological perspectives, may help identify sustainable solutions to reinforce local social-ecological systems and livelihoods. Understanding such systems requires building bridges between local knowledge and scientific knowledge. A study conducted by Marie et al. (2009) on local practices related to an endangered group of tree species in Madagascar, the seven endemic baobab species (Adansonia spp.), shows that conservation narratives about threats relating to Malagasy baobab often attribute these threats to human activities, but neglect consideration of how baobabs are part of local agroecosystems and are often protected, if not cultivated, by local farmers.

\section{Reciprocal relations, tree agency and interconnected multiple valuing systems}

Trees are at the heart of exchanges between humans, other living beings (biodiversity) and intangible entities (Aumeeruddy-Thomas and Michon 2018). The roles of isolated or clustered Ficus individuals as mediators between people and ancestors and other intangible entities, as well as between people, their landscape history and their identity, and between people and the animals they hunt or that are perceived as disseminators of seeds (e.g., birds and bats), makes these trees active hubs. The Betsileo do not conceive of Ficus trees as simply passive elements, but as recipients of social actions built upon reciprocal relations between the Betsileo and the 
power of nature, designated in Madagascar as hasina or sacred power, which is likened to God and which can be transmitted by people or plants, as shown for F. lutea in Antananarivo (Aumeeruddy-Thomas et al. 2018). To the Betsileo, trees have a level of agency, because they directly affect people's lives by bringing happiness or protection, or by purifying people of their deeds. They therefore also affect social organization and decisions, and in that respect form part of the hybrid communities that link humans to other living beings, as is true for many other indigenous peoples and local communities across the planet (Stepanoff and Vigne 2019). Diver et al. (2019) argue that in Madagascar, taking into account reciprocal relations between humans and biodiversity is crucial to improve conservation approaches. In particular, their study shows that local rules of access to resources and places reinforce reciprocal relations. In our study sites, the distribution of Ficus species across the landscape does not follow haphazard patterns, and associations of different Ficus species with different socio-ecological facets, i.e., specific places having strong meanings, leads to formulation of rules that guide access to and management of these places and the Ficus they include. These rules have to be considered in collaborative approaches for biodiversity conservation if local livelihoods are to be sustained.

Past and present uses of biodiversity, transmission of knowledge and local formal and informal rules guiding access and management approaches to resources contribute to enhance relational values that link people to landscapes (Chan et al. 2016). This needs full consideration if conservation efforts are truly to engage with indigenous peoples and local communities (Diaz et al. 2018).

In addition to their strong social or relational value, Ficus trees also have an ecological value as ecosystem engineers in sacred woodland patches in open agricultural areas in Betsileo rural landscapes. Their economic value is related to their roles in checking erosion and other multiple material uses. An interconnected multipl $\bar{v}$ luing system characterizes the use of isolated and clustered of Ficus trees in the Betsileo rural landscapes. As discussed by Pascual 
665

666

667

668

669

670

671

672

673

674

675

676

677

678

679

680

681

682

683

684

685

686

687

688

689

et al. (2017), multiple valuing systems are crucial to understand and sustain to attain sustainable development objectives.

\section{Tree management and propagation practices and distribution}

Naming and uses are similar or confounded between the Betsileo and the Merina cultural groups who live in the region of Antananarivo, where we conducted a previous study. In that study we focused on F. lutea in the sacred hills of Antananarivo, and we showed that the Merina used many symbols to portray their supremacy, among them F. lutea. Trees of this species were planted by stem cuttings in new places they had 'acquired' during their unification of Madagascar as a state (Aumeeruddy-Thomas et al. 2018). Similar practices have been described in continental Africa, where Ficus trees were planted in front of conquerors' houses or on their tombs to mark their acquisition of a new territory (Dury 1991). The use of the name amonta for F. lutea by the Betsileo is very similar to its Merina name amontana. Both in Antananarivo and in the Betsileo sites, F. lutea is associated with similar sets of symbolic values. All this suggests a strong Merina influence. In the rural landscape, $F$. lutea is mainly planted from stem cuttings by noble classes. It regenerates from seed only in the cliffs area (Zone C), where ancient hova (Betsileo nobles) lived (Moreau 2002). The absence of F. lutea in Zone A- Eastern forest (except in the humid Tanala side located on the eastern slope of the mountain ridge) suggests that it may have been brought into the Betsileo region by the Merina. The same pattern applies to F. trichopoda, which in the Betsileo study sites occurs only (except for rare seedlings) as planted individuals propagated from stem cuttings. This species bears the same name as $F$. polita in Antananarivo (aviavy). This pattern also applies to F. reflexa, which bears the same name (nonoka) in Betsileo and Merina. The above species are considered to have the power to protect humans and zebus, to purify people, or to bring happiness (but also death). These beliefs

all portray the supernatural power accorded to them and a strong influence of the powerful Merina. 
691

692

693

694

695

696

697

698

699

700

701

702

703

704

705

706

707

708

709

710

711

712

713

The diverse distribution patterns of $F$. tiliifolia, F. reflexa and F. lutea show very distinct dynamics that are taken into account in efforts of local people to protect them.

\section{Ficus tiliifolia}

While $F$. tiliifolia is accorded a positive value in agriculture for its role in fertilizing soils, it can also negatively affect agricultural production. The tree is deciduous (i.e., leaves of an individual are shed synchronously) but individual trees differ in when leaves are shed. Some individuals shed leaves at a time when the falling leaves can harm young rice seedlings. Farmers may decide to cut such trees. Martin et al. (2009) suggested that protection of Ficus species by the Betsileo was linked to respect for ancestors' practices, and roles of taboos (fady). The present study corroborates these findings and revises ideas about taboos. Taboos are often considered instrumental in reinforcing conservation but they can be lifted (FernandezLlamazares et al. 2018). Ethnobotanical and ethnohistorical approaches taken in our study show that several factors - historical, symbolic, but also economic — contribute to explaining why, what and where Ficus trees are protected in Betsileo rural landscapes. Patterns of protection are not linked to any strict taboo. Although people respect the practices of ancestors and refer to this in the first place, the Betsileo give numerous other reasons to explain why they have protected $F$. tiliifolia trees. Four major and interlinked reasons are given: (1) the numerous practical uses of this species, e.g. fertilizing soils and improving soil water content; (2) analogies between people and trees ; (3) its role as food for children and cattle; (4) its role as an identity marker for Betsileo people. In Sahabe, where F. tiliifolia is rare, people pay less attention to this tree than in Ambendrana. A possible explanation is that Sahabe is located at a higher altitude and the climate is colder and less suitable for this species. Furthermore, the rural landscape in Sahabe shows a larger extension of herbaceous grasslands associated with a higher 
level of pastoral activities (Fig 4). As explained by Kottak (1977), the Arindrano chiefdom was probably more based on pastoralism than the Lalaina kingdom. Virtually restricted to forest environments, F. tiliifolia could not survive in the savannah-type environments of Sahabe (just as its population is now shrinking in the open areas created by sedentarized agriculture in Ambendrana).

\section{Ficus reflexa}

Ficus reflexa is protected owing to its multiple uses. It is abundant in a large area of plains and near the cliffs, areas that were occupied by the Betsileo before periods of insecurity in the 17th and 18th centuries, and then occupied by the Merina in the 19th century, the area defined in this study as Zone $\mathrm{C}-15$ roofs area. The distribution of $F$. reflexa in this zone is thus the result of historical accumulations of trees of this species planted by people, reflected in its abundance in abandoned villages (tanana haola) and in zebu corrals, both abandoned ones and those presently used.

\section{Ficus lutea}

Ficus lutea is also protected in Zone C-15 roofs area, but is less actively planted due to its association with noble classes. It is therefore much less common than F. reflexa, although it has multiple uses.

\section{Implications for conservation and potential collaborative approaches}

Conservation efforts increasingly consider anthropogenic landscapes made of the co-existence of agroecosystems and other elements such as forests, pastures, fallow land, that contribute to connectivity and habitat diversity (Perfecto and Vandermeer 2010; Manning et al 2019). Isolated and clustered Ficus individuals are key elements of Betsileo rural landscapes. Given the multiple economic, relational and ecological values associated with them, Ficus trees can 
contribute both to biodiversity conservation and to support social-ecological systems built on local knowledge. "Community-based" approaches that were developed previously in Madagascar — and more widely across the planet — have not led to the expected results, (Ward et al. 2014, Blanc-Pamard and Fouroux 2004). This suggests that multiple-evidence and collaborative approaches that build on synergies between local and scientific knowledge to understand multiple valuing systems should be further implemented (Pascual et al. 2017, Tengo et al. 2014). Practical collaborative conservation work requires long-term involvement of scientists, conservation managers and local communities (e.g. Lama et al. 2001: Diver et al. 2019). Our engagement in collaborative approaches started with the co-writing of a paper with local experts (Rafidison et al. 2016). Based on our experience, and on findings by other authors about the roles played by trees in open agricultural landscapes in Madagascar (e.g. Marie et al. 2009), we suggest a few rules of thumb for developing collaborative approaches that conserve biodiversity and sustain local social-ecological systems. The following steps are some approaches that we suggest:

- Characterizing rural landscapes and their complexities based on i) local knowledge and other tools (e.g. remote sensing, ecological analysis, naturalists' knowledge of biodiversity) and ii) a fine comprehension of social-ecological facets, distribution of practices and changes in practices in the landscape, over time;

- Identifying key elements such as Ficus trees through multiple evidence-based approaches based on local knowledge and joint investigations of ecological, ethnobotanical and anthropological aspects;

- Defining together through focus-group discussions with elders, men, women, and children, the key roles of specific species as indicators of well-being and their diverse values for people and how they affect other groups of species. Discussing potential plans for supporting the protection of such species, with due recognition of values, of who is 
entitled to plant each species, and how and where (in which specific social-ecological facets) each can be propagated;

- Avoiding inventing "local" institutions that are not truly appropriatec $\overline{\bar{l}}$ local people, and building a joint understanding of collective visions and rules of access to resources.

\section{CONCLUSION}

The roles of trees in live hedges, in small woodland patches or as isolated elements in rural landscapes are known, especially in agroforestry systems. However, the multiple social, historical and political roles of trees in open landscapes have rarely been discussed in relation to collaborative conservation approaches that consider local social-ecological dynamics. This case study provides an understanding of how the Betsileo people associate multiple relational, economic and ecological values with Ficus trees at the landscape level. The ecological role of Ficus trees as stepping-stones are known to enhance connectivity and facilitate re-afforestation in fragmented rural landscapes. They may be considered for their potential to improve the management of biodiversity and for their multiple local values. Propagation techniques applied to each species, and the places where trees of each species are allowed to grow, are linked to interconnected cultural, ecological, historical and economic contexts. This study suggests avenues regarding approaches to understanding the multiple values of trees in open rural landscapes and their potential roles for supporting conservation of local social-ecological systems outside protected areas. 
Acknowledgements

788

789

790

791

792

793

794

795

796

797

798

799

800

801

802

803

804

805

806

807

This study was funded by GIP Ecofor (Groupement d'Intérêt Public pour les écosystèmes forestiers). Funding to support the first author's stay in France was obtained from the Service Culturel de la Coopération Française of the French Embassy in Antananarivo. The Centre for Functional and Evolutionary Ecology (CEFE UMR 5175), CNRS in Montpellier hosted the first author and helped with data analysis and identification of Ficus species. We are grateful to the communities of Ambendrana and Sahabe for their willingness to participate in the interviews. We especially thank our guides Mr. Rajean Marie, Mr. Rakotomaro, Mr. Ramily and Mr. Roger for following us during our field studies and for accepting to participate in a workshop of the Intergovernmental Platform for Biodiversity and Ecosystem Services (IPBES) in Antananarivo (25-27 January 2016). We are grateful to Mr Dominique Hervé (Institut de Recherche pour le Développement) for local logistical support and to $\mathrm{Mr}$ Vonjison Rakotoarimanana for his support in data analysis. We heartfully thank Professor Doyle Mckey for his multiple comments on the manuscript and for having accepted to read the last version.

\section{REFERENCES}

Aumeeruddy-Thomas Y (2003) Conflits de pouvoir et de représentations à l'interface des sociétés et des aires protégées : le cas du Parc National Kerinci Seblat en Indonésie. Bois et Forêts des Tropiques. Special Issue : Forêts Détruites ou Reconstruite, 278 : 77-91

Aumeeruddy-Thomas Y (2013) Savoirs locaux et biodiversité : interactions sociétés et aires protégées. Etudes comparatives : Indonésie, Népal, Pakistan et France In: Juhé-Beaulaton D, 
Cormier-Salem M-C, de Robert P, Roussel B (ed) Effervescence patrimoniale au Sud. Entre Nature et Sociétés. IRD Editions, Marseille, pp 55-75

Aumeeruddy Y, Bakels J (1994) Management of a sacred forest in the Kerinci valley, Central Sumatra: an example of conservation of biological diversity and its cultural basis. JATBA Journal d'Agriculture Tropicale et de Botanique Appliquée 31 (2): 39-65.

Aumeeruddy-Thomas Y, Moukhli M, Haouane H, Khadari B (2017) Ongoing domestication and diversification in grafted olive-oleaster agroecosystems in Northern Morocco. Regional Environmental Change 17:1315-1328 DOI 10.1007/s10113-017-1143-3

Aumeeruddy-Thomas Y, Hmimsa Y (2019) Fig and olive domestication in the Rif, Northern Morocco. Entangled human and tree lives and history. In: Stepanoff C, Vigne J-D (ed) Hybrid Communities: Biosocial Approaches to Domestication and Other Transspecies Relationships, Routeledge, London, pp 179-198

Aumeeruddy-Thomas Y, Michon G (2018) Agroforestry. In: (ed) Callan H The International Encyclopedia of Anthropology. John Wiley \& Son. DOI: 10.1002/978111892439

Aumeeruddy-Thomas Y, Rafidison V, Kjellberg F and Hossaert-McKey M (2018) Sacred hills of Imerina and the voyage of Ficus lutea Vahl (Amontana) in Madagascar. Acta Oecologica 90:18-27. https://doi.org/10.1016/j.actao.2018.04.005.

Barthélémy D, and Caraglio Y (2007) Plant architecture: A dynamic, multilevel and comprehensive approach to plant form, structure and ontogeny. Annals of Botany, 375-407. https://doi.org/10.1093/aob/mcl260

Beaujard Ph (2009) La place et les pratiques des devins-guérisseurs dans le Sud-Est de Madagascar. In: Nativel D, Rajaonah FV (ed) Madagascar revisitée. En voyage avec Françoise Raison-Jourde. Karthala Paris, pp 259-285 
Berkes F, and C Folke (ed) (1998) Linking sociological and ecological systems: management practices and social mechanisms for building resilience. Cambridge University Press, New York

Blanc-Pamard C (1986) Dialoguer avec le paysage ou comment l'espace écologique est vu et pratiqué par les communautés rurales des Hautes Terres malgaches. In: Ghatelin Y,

Riou G (ed) Milieux et paysages, Masson, Paris, pp 17-35

Blanc-Pamard C, Ralaivita M (2004) Ambendrana, un territoire d'entre deux : conversion et conservation de la forêt (Corridor Betsileo, Madagascar) Fianarantsoa, IRD/CNRE. CNRS/EHESS/CEAF Unpublished report, 86p

Blanc-Pamard C and Fauroux E. (2004) L'illusion participative, exemples ouest-malgaches Revue Autrepart, 3 (31) : 3-19

Blanc-Pamard C and Rakoto Ramiarantsoa H (2007) Normes environnementales, transferts de gestion et recompositions territoriales en pays betsileo (Madagascar). La gestion contractualisée des forêts. Natures Sciences Sociétés, NSS Dialogues, EDP Sciences, 15:253-268. doi 10.1051/nss:2007055

Burrows J. and S. Burrows (2003) Figs of Southern and South Central Africa, Umdaun Press, Hatfield

Carrière SM (2002) Orphan trees of the forest. Why do Ntumu farmers of southern Cameroon protect trees in their swidden fields? Journal of Ethnobiology 22 (1): 133-162

Carrière SM, Andrianotahiananahary H, Ranaivoarivelo N and Randriamalala J (2005) Savoirs et usages des recrus post-agricoles du pays Betsileo : valorisation d'une biodiversité oubliée à Madagascar. VertigO : la revue électronique en sciences de l'environnement 6, No 1, http://journals.openedition.org/vertigo/3047 ; DOI : 10.4000/vertigo.3047 
Chan KM. A., Balvanera P, Benessaiah K, et al. (2016). Why protect nature? Rethinking values and the environment. Proceedings of the National Academy of Sciences 113(6): 1462-1465. http://www.pnas.org/content/113/6/1462.full

Dalecky A, Kerdelhue C, Johnson S, Razafindratsita VR, Grassi C, Razafiarimalala AC, Overdorff DJ, Rasplus J-Y (2003) Moraceae, Ficus and associated fauna. In: Goodman SM, Benstead JP (ed) The natural history of Madagascar. The University of Chicago Press, Chicago, pp 322-334

Díaz S, Pascual U, Stenseke M, Martín-López B, Watson RT, Molnár Z, Hill R, Chan K M A, Baste IA, Brauman KA, Polasky S, Church A, Lonsdale M, Larigauderie A, Leadley P W, van Oudenhoven APE, van der Plaat F, Schröter M, Lavorel S, Aumeeruddy-Thomas Y, Bukvareva E, Davies K, Demissew S, Erpul G, Failler P., Guerra CA, Hewitt C L, Keune H, Lindley S, Shirayama Y (2018) Assessing nature's contributions to people. Science 359 (6373): 270-272 DOI: 10.1126/science.aap8826

Diver S, Vaughan M, Baker-Médard M, Lukacs H (2019) Recognizing "reciprocal relations" to restore community access to land and water. International Journal of the Commons 13(1): 400-429. https://doi.org/10.18352/ijc.881

Dubois H (1938) Monographie des Betsileos. Institut d'ethnologie, Paris

Dury S (1991) Ethnobotanical approach to Ficus in northern Cameroon, Master's Dissertation UNESCO/Man and the Biosphere Program, Paris.

Eden H, Cottee-Jones W, Bajpai O, Chaudary 1B, Whittaker WR (2015) Isolated Ficus trees deliver dual conservation and development benefits in a rural landscape. Ambio, 44: 678-684 https://doi.org/10.1007/s13280-015-0645-9 
876 Ellen R (1996) The cognitive geometry of nature: a contextual approach. In: Descola P, Palsson

877 G (ed) Nature and society. Anthropological perspectives. Routledge London pp 103-123.

878 Fernández-Llamazares A, López-Baucells A, Rocha R, Andriamitandrina SFM, Andriatafika Z

879 E, Burgas D, Temba E M, Torrent L and Cabeza M (2018) Are sacred caves still safe havens

880 for the endemic bats of Madagascar? Oryx: Fauna \& Flora International 52:271-275

881 doi:10.1017/S0030605317001648

882 Friedberg C (1986). Classifications populaires des plantes et modes de connaissances.? In:

883 Tassy P (ed) L'ordre et la diversité du vivant. Quel Statut scientifique pour les classifications 884 biologiques ? Fondation Diderot, Fayard, Paris

885

886

887

888

889

890

891

892

893

894

895

896

897

Ganzhorn JU, Wilmé L, Mercier J-L (2014) Explaining Madagascar's biodiversity. In: Scales IR (ed), Conservation and environnemental management in Madagascar. Earthscan Routledge New York, pp 17-44

Giambrone N S J (1973) Teto anivon'ny riaka. Centre de formation pédagogique. 5ème edition, Ambozontany, Fianarantsoa

Goodman SM, Benstead JP (2003) The natural history of Madagascar. The University of Chicago Press. Chicago and London, pp 58-1490

Goodman, SM and Ganzhorn JU (1997) Rarity of figs (Ficus) on Madagascar and its relationship to a depauperate frugivore community. Revue d'Ecologie Terre et Vie 52: 21-29

Goodman SM et Razafindratsita VR (2001) Inventaire biologique du Parc national Ranomafana et du couloir forestier qui relie au Parc national d'Andringitra. CIDST, Antananarivo-

Madagascar 
Hallé, F, Oldeman RAA and Tomlinson PB (1978) Tropical trees and forests. An architectural analysis. Springer-Verlag, Berlin

Harper J (2003) Memories of ancestry in the forests of Madagascar. In: Stewart P.J. ad Strathern (ed) A Landscape memory and history. Anthropological perspectives. Pluto Press, London, pp $89-107$

Harrison RD, Shanahan M (2005) Seventy-seven ways to be a fig: an overview of adiverse assemblage offigs in Borneo. In: Roubik, DW, Sakai S, HamidKarim AA (ed) Pollination ecology and the rain forest. Springer, New York, pp 111-127 doi: 10.1007/0-387-27

Jones, J. P. G., Ratsimbazafy, J., Ratsifandrihamanana, A. N., Watson, J. E. M., Andrianandrasana, H. T., Cabeza, M. et al. (2019). Last chance for Madagascar's biodiversity. Nature Sustainability, Nature Sustainability, 2:350-352. https://doi.org/10.1038/s41893-0190288-0

Kottak CP (1977) The process of state formation in Madagascar. American Ethnologist 4:136155 Stable URL: https://www.jstor.org/stable/643527

Kjellberg F, Jousselin E, Hossaert-McKey M, Rasplus JY (2005) Biology, ecology and evolution of fig-pollinating wasps (Chalcidoidea, Agaonidae). In: Raman A, Schaefer CW and Withers TM (ed) Biology, ecology, and evolution of gall-inducing arthropods, Science publishers, Plymouth, pp 539-572

Kjellberg F, Aumeeruddy-Thomas Y, Benoit L, Carrière SM, Hossaert-McKey M, Rakouth B, Edmond R, Rabevohitra R, Rafidison V (2010) Corridor de végétation et conservation d'un groupe clé de voute de la biodiversité, le cas des Ficus et des communautés associées, Rencontre ECOFOR 
Kull CA, Carrière SM, Moreau S, Rakoto Ramiarantsoa H, Blanc-Pamard C, Tassin J (2013) Melting pots of biodiversity: tropical smallholder farm landscapes as guarantors of sustainability. Environment Environment: Science and Policy for Sustainable Development. 611. http://dx.doi.org.inee.bib.cnrs.fr/10.1080/00139157.2013.765307

Kun A, Obourny B and Diekmann U (2009) Intermediate landscape disturbance maximizes metapopulation density. Landscape Ecology 24: 1341-1350 DOI: 10.1007/s10980-009-9386-0

Kunwari R, Rainer W. Bussmann (2006) Ficus (Fig) species in Nepal: a review of diversity and indigenous uses, Lyonia, $11: 85-97$

Manning AD, Fischer J, Lindenmayer DB (2006) Scattered trees are keystone structures: Implications for conservation. Biological Conservation 132: 311-321. doi:10.1016/j.biocon.2006.04.023

Manning P, Loos J, Barnes A D, P Battary (2019) Transferring biodiversity- ecosystem function research to the management of 'real-world' ecosystems.

https://doi.org/10.1016/bs.aecr.2019.06.009

Marie CN, Sibelet N, Dulcire M, Rafalimaro M, Danthu P, Carrière SM (2009). Taking into account local practices and indigenous knowledge in an emergency conservation context in Madagascar. Biodiversity and Conservation, 18, 2759-2777. https://doi.org/10.1007/s10531009-9672-9

Martin E, Ratsimisetra L, Laloë F, Carrière SM (2009) Conservation value for birds of traditionally managed isolated trees in an agricultural landscape of Madagascar. Biodiversity and Conservation 18: 2719-2742

McConnell, W J, Sweeney S P (2005). Challenges of forest governance in Madagascar. The Geographical Journal 171: 223-238. https://doi.org/10.1111/j.1475-4959.2005.00162.x 
Mora C, Sale PF (2011) Ongoing global biodiversity loss and the need to move beyond protected areas: a review of the technical and practical shortcomings of protected areas on land and sea. Marine Ecology Progress Series 434: 251-266. doi.org/10.3354/meps09214

Moreau S (2002) Les gens de la lisière. La forêt, l'arbre et la construction d'une civilisation paysanne Sud Betsileo, Madagascar. Dissertation, Universty of Paris X

Nazarea DV (1999) Cultural memory and biodiversity. The University of Arizona Press, Tucson

Oldeman RAA and van Rijk J (1991) Diagnosis of the temperament of tropical rain forest trees. In: (ed) Gomez-Pompa, Whitmore and Hadley M Rainforest regeneration and management. MAB series 6, UNESCO and Parthenon Books, Carnford, pp.21-65

\section{Pascual U, Balvanera P, Díaz S, Pataki G, Roth E, Stenseke M et al. (2017) Valuing nature's} contributions to people: the IPBES approach. Current Opinion in Environmental Sustainability 26-27: 7-16. https://doi.org/10.1016/j.cosust.2016.12.006

Perfecto, I., \& Vandermeer, J. (2010) The agroecological matrix as alternative to the landsparing / agriculture intensification model. 107 (13): 5786-5791. https://doi.org/10.1073/pnas.0905455107

Rafidison, VM (2013) Ethnobiologie et écologie des Ficus des terroirs Betsileo et du corridor Ranomafana - Andringitra (Madagascar). Dissertation University Antananarivo

Rafidison VM, Rabevohitra R, Aumeeruddy-Thomas Y, Hossaert-McKey M, Rasplus JY, Kjellberg F (2011) Notes taxonomiques et identification des Ficus malgaches. Acta Botanica Gallica 158 (4): 453-472 
Rafidison V, Rakotoanadahy B, Rakototomaro JF, Rafanomezantsoa E, Rasabo E, Rakotozafy R., Aumeeruddy-Thomas Y (2016) Pratiques et connaissances naturalistes des communautés Betsileo: lisière du corridor forestier Andringitra-Ranomafana, Madagascar. InRoué M., Césard N., Adou Yao YC, Oteng - Yeboah : (ed) A Indigenous and local knowledge of biodiversity and ecosystem services in Africa, UNESCO, Paris, p 96-

\section{7 http://climatefrontlines.org/sites/default/files/ipbes/IPBES_in_Africa_2015.pdf}

Raherisoanjato D (1984) Origines et évolution du royaume de l'Arindrano jusqu'au $19^{\text {ème }}$ siècle. Contribution à l'histoire régionale de Madagascar. Travaux et document nº XXII. Musée d'art et d'archéologie. Université de Madagascar, Antananarivo

Rakoto Ramiarantsoa H, Blanc-Pamard C, Andriantseheno D, Ramamonjy H (2014) Des territoires et des contrats au service de l'environnement. Le Lalangina, sur le versant ouest du COFAV (corridor forestier Ambositra Vondrozo) à Madagascar. European Journal of Geography. Environnement, nature, paysage, document 691, http://journals.openedition.org/cybergeo/26511, DOI : 10.4000/cybergeo.26511

Renard D, Tilman D (2019) National food production stabilized by crop diversity. 571 (7764): 257-260. doi: 10.1038/s41586-019-1316-y.

Rival L (1998) Trees, from symbols of life and regeneration to political artefacts. In: L. Rival (ed) The social life of trees: anthropological perspectives on tree symbolism, Berg, New York, pp. 1-36

Shanahan M, Samson SO, Compton SG and Corlett R (2001) Fig-eating by vertebrate frugivores: a global review. Biological Reviews 76: 529-72

Stepanoff C, Vigne J-D, (2019) Hybrid Communities: Biosocial Approaches to Domestication and Other Transspecies Relationships, Routeledge, London 
987 Tengö, M., Brondizio, E. S., Elmqvist, T., Malmer, P., \& Spierenburg, M. (2014). Connecting 988 diverse knowledge systems for enhanced ecosystem governance: The multiple evidence base 989 approach. Ambio 43(5): 579-591. https://doi.org/10.1007/s13280-014-0501-3

990 Waeber PO, Wilmé L, Ramamonjisoa B, Garcia C, Rakotomalala D, Rabemananjara ZH (2015) 991 Dry forests in Madagascar: neglected and under pressure. International Forestry Review, 992 17:127-148 (2015). https://doi.org/10.1505/146554815815834822

993 Ward C, Stringer LC, Holmes G (2018) Protected area co-management and perceived 994 livelihood impacts. Journal of Environmental Management 228:1-12. 995 https://doi.org/10.1016/j.jenvman.2018.09.018

996 Walter A, Sam C (1999) Fruits d'Océanie, IRD Editions, Marseille

997 Wilson D, Wilson A (2013) Figs as a global spiritual and material resource for humans. Human 998 Ecology 41: 459-464. DOI: 10.1007/s10745-013-9582-z 


\begin{tabular}{|c|c|c|c|c|c|c|c|c|c|}
\hline Section & Espèces & $\begin{array}{l}\text { Mating } \\
\text { System }\end{array}$ & Life form & $\begin{array}{l}\text { Maximum } \\
\text { height }(\mathbf{m})\end{array}$ & $\begin{array}{c}\text { Placement } \\
\text { of } \\
\text { inflorescences } \\
\end{array}$ & $\begin{array}{c}\text { Maximum } \\
\text { diameter } \\
\text { of fruits } \\
(\mathbf{c m}) \\
\end{array}$ & Habitat & $\begin{array}{l}\text { Altitude } \\
\quad(\mathbf{m})\end{array}$ & Distribution \\
\hline Sycidium & $\begin{array}{l}\text { F. politoria } \\
\text { Lamarck } \\
\text { (synonym, F. } \\
\text { soroceoides) }\end{array}$ & d & $\begin{array}{l}\text { Shrub or } \\
\text { treelet }\end{array}$ & 8 & $\mathrm{C}$ & $1 \mathrm{~F}$ & $\begin{array}{l}\text { Understory, } \\
\text { abundant in } \\
\text { patches, } \\
\text { often in } \\
\text { riverine } \\
\text { forest }\end{array}$ & $\begin{array}{l}0-1700 \\
(2500- \\
2800)\end{array}$ & $\mathrm{M}(\mathrm{E}, \mathrm{C}, \mathrm{N})$ \\
\hline \multirow{3}{*}{ Sycomorus } & $\begin{array}{l}\text { F. tiliifolia } \\
\text { Baker }\end{array}$ & $\mathrm{m}$ & Tree & $20(25)$ & $\mathrm{C}, \mathrm{A}$ & $1,5-5 \mathrm{~F}$ & $\begin{array}{l}\text { Forest, } \\
\text { sometimes } \\
\text { planted }\end{array}$ & $0-1700$ & $\begin{array}{l}M \text { (all parts of the island } \\
\text { islands) and Co }\end{array}$ \\
\hline & $\begin{array}{l}\text { F.botryoides } \\
\text { Baker }\end{array}$ & $\mathrm{m}$ & Tree & 25 & $\mathrm{C}, \mathrm{A}$ & $2(3,8) \mathrm{F}$ & $\begin{array}{l}\text { Forest, along } \\
\text { rivers }\end{array}$ & $0-1600$ & $\mathrm{M}(\mathrm{E}, \mathrm{C}, \mathrm{N})$ \\
\hline & $\begin{array}{c}\text { F. trichoclada } \\
\text { Baker }\end{array}$ & $\mathrm{m}$ & Tree & 15 & $\mathrm{C}, \mathrm{A}$ & $3(4) \mathrm{F}$ & $\begin{array}{c}\text { Along } \\
\text { streams }\end{array}$ & $100-1500$ & M \\
\hline \multirow{3}{*}{ Galoglychia } & $\begin{array}{l}F . \text { lutea } \mathrm{Vahl} \\
\text { (synonym } F \text {. } \\
\text { baronii) }\end{array}$ & $\mathrm{m}$ & $\begin{array}{l}\text { Hemi- } \\
\text { epiphytic }\end{array}$ & 23 & A & $2,5(3,5) \mathrm{F}$ & $\begin{array}{l}\text { In forest, } \\
\text { often along } \\
\text { rivers, } \\
\text { marshes, and } \\
\text { seacoast } \\
\end{array}$ & $0-1500$ & $\mathrm{M}, \mathrm{Co}, \mathrm{Se}, \mathrm{CA}$ \\
\hline & $\begin{array}{l}\text { F. trichopoda } \\
\text { Baker }\end{array}$ & $\mathrm{m}$ & $\begin{array}{l}\text { Shrub or } \\
\text { tree }\end{array}$ & $10(20)$ & A & $2 \mathrm{~F}$ & $\begin{array}{c}\text { Savanna } \\
\text { woodland, in } \\
\text { marshy } \\
\text { places } \\
\end{array}$ & $500-1100$ & $\begin{array}{c}\mathrm{M}(\mathrm{W}, \text { planted in Center }), \\
\mathrm{CA}\end{array}$ \\
\hline & $\begin{array}{l}\text { F. reflexa } \\
\text { Thunberg }\end{array}$ & $\mathrm{m}$ & $\begin{array}{l}\text { Hemi- } \\
\text { epiphytic }\end{array}$ & $10(30)$ & A & $1,2 \mathrm{D}$ & $\begin{array}{l}\text { In various } \\
\text { types of } \\
\text { forest } \\
\end{array}$ & $0-1700$ & $\begin{array}{l}\text { M (all parts of the island), } \\
\text { Me. other subspecies in Se } \\
\text { (incl. AL), Co }\end{array}$ \\
\hline
\end{tabular}




\begin{tabular}{|c|c|c|c|c|c|c|c|c|}
\hline F. polita Vahl & $\mathrm{m}$ & $\begin{array}{l}\text { Hemi- } \\
\text { epiphytic }\end{array}$ & $15(40)$ & $\mathrm{C}$ & $4 \mathrm{~F}$ & $\begin{array}{c}\text { Evergreen } \\
\text { (humid and } \\
\text { gallery) } \\
\text { forest }\end{array}$ & $600-700$ & $\mathrm{M}$ (all island?), CA \\
\hline
\end{tabular}

Source: Dalecky et al. 2003, revised 2010 by F. Kjellberg, V. Rafidison. and Y. Aumeeruddy-Thomas

d:dioecious; m: monoecious; $R$ : ramiflorous; C: cauliflorous; A: axillary

D: dry, F: fresh

M (E, C, N, W, S): Madagascar (east, center, north, west, south), Co: Comoro islands; Se: Seychelelles; CA: Continental Africa; Me: Mascarenes; Al: Aldabra 


\begin{tabular}{lcc}
\hline Site & Ambendrana & Sahabe \\
\hline Men & 45 & 59 \\
Women & 19 & 31 \\
Total & 64 & 90 \\
Precision on informants ages & \\
Children < 12years & 11 & 12 \\
Youngsters 12-18 & 1 & 4 \\
years & & \\
Young parent 20-40 & 29 & 52 \\
years & 23 & 22 \\
Old persons & & \\
\hline
\end{tabular}




\begin{tabular}{|c|c|c|}
\hline Type & Terminology & Signification \\
\hline \multirow[t]{8}{*}{$\begin{array}{l}\text { Natural or anthropogenic } \\
\text { vegetation types }\end{array}$} & Tapoka & $\begin{array}{l}\text { Marshy areas not yet transformed into } \\
\text { paddy fields }\end{array}$ \\
\hline & Alagasy & $\begin{array}{l}\text { Literally, "malagasy forest", stands for } \\
\text { non-disturbed forests }\end{array}$ \\
\hline & Alakininina & Eucalypt forest \\
\hline & Atikifafa & $\begin{array}{l}\text { Literally, "within the herbaceous } \\
\text { savanna", an area that was never } \\
\text { cultivated but has been burned for } \\
\text { pasture lands }\end{array}$ \\
\hline & $\begin{array}{l}\text { Kapoka } \\
\text { (Ambendrana) } \\
\text { Popoka (Sahabe) }\end{array}$ & $\begin{array}{l}\text { Post- agricultural regrowth or forest or } \\
\text { bushy vegetation fallows }\end{array}$ \\
\hline & Kilanjy & $\begin{array}{l}\text { Worn out land with a fallow of } \\
\text { herbaceous for an undetermined period }\end{array}$ \\
\hline & Kirihitra & Bushy vegetation \\
\hline & Songonala & $\begin{array}{l}\text { Literally "forest tuft" meaning an } \\
\text { isolated small wood. }\end{array}$ \\
\hline \multirow[t]{8}{*}{ Agricultural land use } & Dobo & Fish pond \\
\hline & Kipahy & $\begin{array}{l}\text { Cultivated terraces, most often irrigated } \\
\text { paddy fields }\end{array}$ \\
\hline & Lalankely & Path \\
\hline & Tanimboankazo & $\begin{array}{l}\text { Literally "land of fruit trees" meaning } \\
\text { orchards }\end{array}$ \\
\hline & Tanimboly & Literally "cultivated land": the field \\
\hline & Tsihintany & $\begin{array}{l}\text { Literally, « land mat » : threshing } \\
\text { ground }\end{array}$ \\
\hline & Valamparihy & Mud walls protecting rice fields \\
\hline & Valanomby & Zebu stockyard \\
\hline \multirow[t]{3}{*}{ Topographic element } & Amorotambina & $\begin{array}{l}\text { The lower border of hill slopes } \\
\text { generally located just above paddy } \\
\text { fields }\end{array}$ \\
\hline & Lohasaha & The head of the field or valley \\
\hline & Tambina & The lower part of hill slopes \\
\hline \multirow[t]{4}{*}{$\begin{array}{l}\text { Extraordinary or specific } \\
\text { natural element }\end{array}$} & $\begin{array}{l}\text { Hara } \\
\text { (Harambato) }\end{array}$ & Rocky cliffs \\
\hline & Renirano & $\begin{array}{l}\text { Literally "the mother of the wate"r: a } \\
\text { river }\end{array}$ \\
\hline & Riandrano & A rivulet \\
\hline & Vatobe & Big rock \\
\hline \multirow[t]{2}{*}{ Historical site } & Aritsa & $\begin{array}{l}\text { Sacred wood where utensils and } \\
\text { garments that have been used during } \\
\text { burial ceremonies are thrown away }\end{array}$ \\
\hline & Fasana & Tombs \\
\hline
\end{tabular}


Tanana Haolo or Valamaty

Vatolahy
Literally, abandoned hamlet or dead hamlet.

Literally, Male stone Stela or megalith which can reach 1 to three meter high and which has a commemorative function.. 


\begin{tabular}{|c|c|c|c|c|c|}
\hline Latin name & Betsileo name & $\begin{array}{c}\text { Literal } \\
\text { translation of } \\
\text { Betsileo name }\end{array}$ & Uses (S) Symbolic ; (M) Material & Reproduction and propagation & Specificities related to protection \\
\hline $\begin{array}{l}\text { F. pachyclada } \\
\text { Baker }\end{array}$ & $\begin{array}{l}\text { kivozy, } \\
\text { mapaly }\end{array}$ & $\begin{array}{c}- \\
\text { scabrous }\end{array}$ & $\begin{array}{l}\text { bark used for making ropes }(\mathrm{M}) \\
\text { firewood }(\mathrm{M}) \\
\text { leaves heal toothache and stomach pain }(\mathrm{M} \text {, } \\
\text { S) }\end{array}$ & natural reproduction by seed - rare & $\begin{array}{l}\text { not found protected elsewhere than } \\
\text { near burial areas, near cliffs }\end{array}$ \\
\hline $\begin{array}{l}F . \text { politoria } \\
\text { Lamarck (Syn. F. } \\
\text { soroceoides) }\end{array}$ & $\begin{array}{l}\text { kivozy } \\
\text { ampaly }\end{array}$ & $\begin{array}{c}- \\
\text { scabrous }\end{array}$ & $\begin{array}{l}\text { bark used for making ropes (M) } \\
\text { fuelwood (M) } \\
\text { leaves heals toothache and stomach pain (M, } \\
\text { S) }\end{array}$ & natural reproduction by seed & grows in forest fallows \\
\hline F. tiliifolia Baker & $\begin{array}{c}\text { ara } \\
\text { voara, }\end{array}$ & $\begin{array}{l}\text { according to/ } \\
\text { linked to } \\
\text { fruit of Ara }\end{array}$ & $\begin{array}{l}\text { tree linked to ancestors (S); presence linked } \\
\text { to divinities and intangible creatures (S) } \\
\text { fallen leaves fertilize soils (M) } \\
\text { roots maintain water in the soil (M/ S) } \\
\text { bark used for making a cloth named ato } \\
(\mathrm{M},) \text { - Previously a coat made with fato could } \\
\text { be exchanged against a zebu (M/S) } \\
\text { the fruit is eaten. Two varieties known : voara } \\
\text { bekoba and voaramalefaka (M) } \\
\text { leaves have medicinal uses : heal stomach ache, } \\
\text { skin disease, facilitates birth (M,S) }\end{array}$ & $\begin{array}{l}\text { natural reproduction by seed, } \\
\text { seedlings sometimes transplanted }\end{array}$ & $\begin{array}{l}\text { local sayings encourage people not } \\
\text { to cut this tree because this would } \\
\text { have negative impacts on soil } \\
\text { water, and would dry up children's } \\
\text { tears and the milk of breast-feeding } \\
\text { women. } \\
\text { protection also due to respect for } \\
\text { ancestors and multiple uses. }\end{array}$ \\
\hline
\end{tabular}




\begin{tabular}{|c|c|c|c|c|c|}
\hline & & & $\begin{array}{l}\text { tree is a marker of territories (M) } \\
\text { tree important in open areas for its shade (M) } \\
\text { wood for previous domestic uses : for making } \\
\text { dishes, spoons, and preparing baskets and } \\
\text { container for feeding livestock and chickens } \\
\text { (M) } \\
\text { latex used as birdlime to catch small birds, } \\
\text { especially the fody (Foudia madagascariensis) } \\
\text { or to repair holes in jugs and buckets (M) } \\
\text { Tree, symbol of fertility (S) }\end{array}$ & & \\
\hline $\begin{array}{l}\text { F.botryoides } \\
\text { Baker }\end{array}$ & fompoha & blow & $\begin{array}{l}\text { fruit eaten }(\mathrm{M}) \\
\text { leaves and fruits stimulate milk production } \\
\text { by breast-feeding women }(\mathrm{S} / \mathrm{M}) \\
\text { bark used in the past to make clothes and } \\
\text { baskets }(\mathrm{M} / \mathrm{S}) \\
\text { tree used to prevent soil erosion }(\mathrm{M})\end{array}$ & $\begin{array}{l}\text { natural reproduction by seed and } \\
\text { planted by cuttings }\end{array}$ & protected due to its multiple uses \\
\hline $\begin{array}{l}\text { F. trichoclada } \\
\text { Baker }\end{array}$ & fompoha & blow & $\begin{array}{l}\text { fruit eaten }(\mathrm{M}) \\
\text { leaves and fruits stimulate milk production } \\
\text { by breast-feeding women }(\mathrm{S} / \mathrm{M}) \\
\text { bark used in the past to make clothes and } \\
\text { baskets }(\mathrm{M} / \mathrm{S}) \\
\text { tree used to prevent soil erosion }(\mathrm{M})\end{array}$ & $\begin{array}{l}\text { natural reproduction by seed and } \\
\text { planted by cuttings }\end{array}$ & protected due to its multiple uses \\
\hline
\end{tabular}




\begin{tabular}{|c|c|c|c|c|c|}
\hline $\begin{array}{l}\text { F. lutea Vahl (syn. } \\
\text { F baronii) }\end{array}$ & $\begin{array}{l}\text { amontana, } \\
\text { amonta }\end{array}$ & abundance & $\begin{array}{l}\text { Tree, symbol of noble classes, richness and } \\
\text { magnificence } \\
\text { Bard used in the past to produce a thread to } \\
\text { make mats (M/S) } \\
\text { fruit eaten (M), } \\
\text { leaves used for making tea (M) } \\
\text { latex used as chewing gum and as birdlime } \\
\text { (M) } \\
\text { leaves fertilize soils (M) } \\
\text { tree useful for shade in open areas (M) } \\
\text { the tree is planted as wind break (M) } \\
\text { leaves and fruits used as fodder for livestock } \\
\text { (M) }\end{array}$ & $\begin{array}{l}\text { natural reproduction by seed and } \\
\text { planted by cuttings }\end{array}$ & $\begin{array}{l}\text { protected if seedlings grow, and } \\
\text { planted, but only by noble classes }\end{array}$ \\
\hline $\begin{array}{l}\text { F. trichopoda } \\
\text { Baker }\end{array}$ & aviavy & coming, arriving & $\begin{array}{l}\text { tree brings happiness when growing } \\
\text { naturally (S) } \\
\text { tree has negative impacts if planted (S) } \\
\text { rare seedlings are protected (M/S) } \\
\text { fruits can be eaten (M) } \\
\text { tree mediator between humans and ancestors } \\
\text { (S) } \\
\text { wood used as a purifier if a fady (taboo) is } \\
\text { not followed (S) }\end{array}$ & $\begin{array}{l}\text { natural reproduction by seed and } \\
\text { planted by cuttings }\end{array}$ & $\begin{array}{l}\text { this tree is never planted, but rare } \\
\text { seedlings are protected du to the } \\
\text { benefits the tree brings. }\end{array}$ \\
\hline
\end{tabular}




\begin{tabular}{|c|c|c|c|c|c|}
\hline $\begin{array}{l}\text { F. reflexa } \\
\text { Thunberg }\end{array}$ & $\begin{array}{c}\text { nonoka, } \\
\text { laza }\end{array}$ & $\begin{array}{l}\text { sucking milk } \\
\text { famous }\end{array}$ & $\begin{array}{l}\text { past symbol of kings and noble classes (S) } \\
\text { increases milk of breast-feeding mothers (M) } \\
\text { When growing on rocks, associated to strength } \\
\text { (S) } \\
\text { Protection of houses against thunder and hail } \\
\text { (M/S) } \\
\text { Fruit eaten (M) } \\
\text { Living hedge (M) } \\
\text { Tree that commemorates ancestors (S) } \\
\text { Tree that brings happiness (S) }\end{array}$ & $\begin{array}{l}\text { natural reproduction by seeds on } \\
\text { stones and planted by cuttings }\end{array}$ & $\begin{array}{l}\text { this tree is protected when growing } \\
\text { naturally but can bec ut if it affects } \\
\text { agricultural production. } \\
\text { it is widely reproduced by cuttings } \\
\text { especially to form live hedges } \\
\text { around zebu corrals. }\end{array}$ \\
\hline F. polita Vahl & Tsaramady & $\begin{array}{l}\text { the one that is } \\
\text { good }\end{array}$ & $\begin{array}{l}\text { Has medicinal uses and increases milk of } \\
\text { breast-feeding wmen (M, S), } \\
\text { Lucky charm for zebu corrals(S), } \\
\text { Protects zebu against thefts and malevolent } \\
\text { deeds (S) } \\
\text { Leaves used for making tea (M) }\end{array}$ & $\begin{array}{l}\text { natural reproduction by seed and } \\
\text { planted by cuttings }\end{array}$ & protected due to its multiple uses \\
\hline
\end{tabular}


Table 1 Ficus species found in the study areas, their major biological and ecological characteristics, habitats and geographical distribution 
Table 2 Sex and age distribution of people interviewed in Ambendrana and Sahabe 
Table 3 The social-ecological facets recorded in Ambendrana and Sahabe 


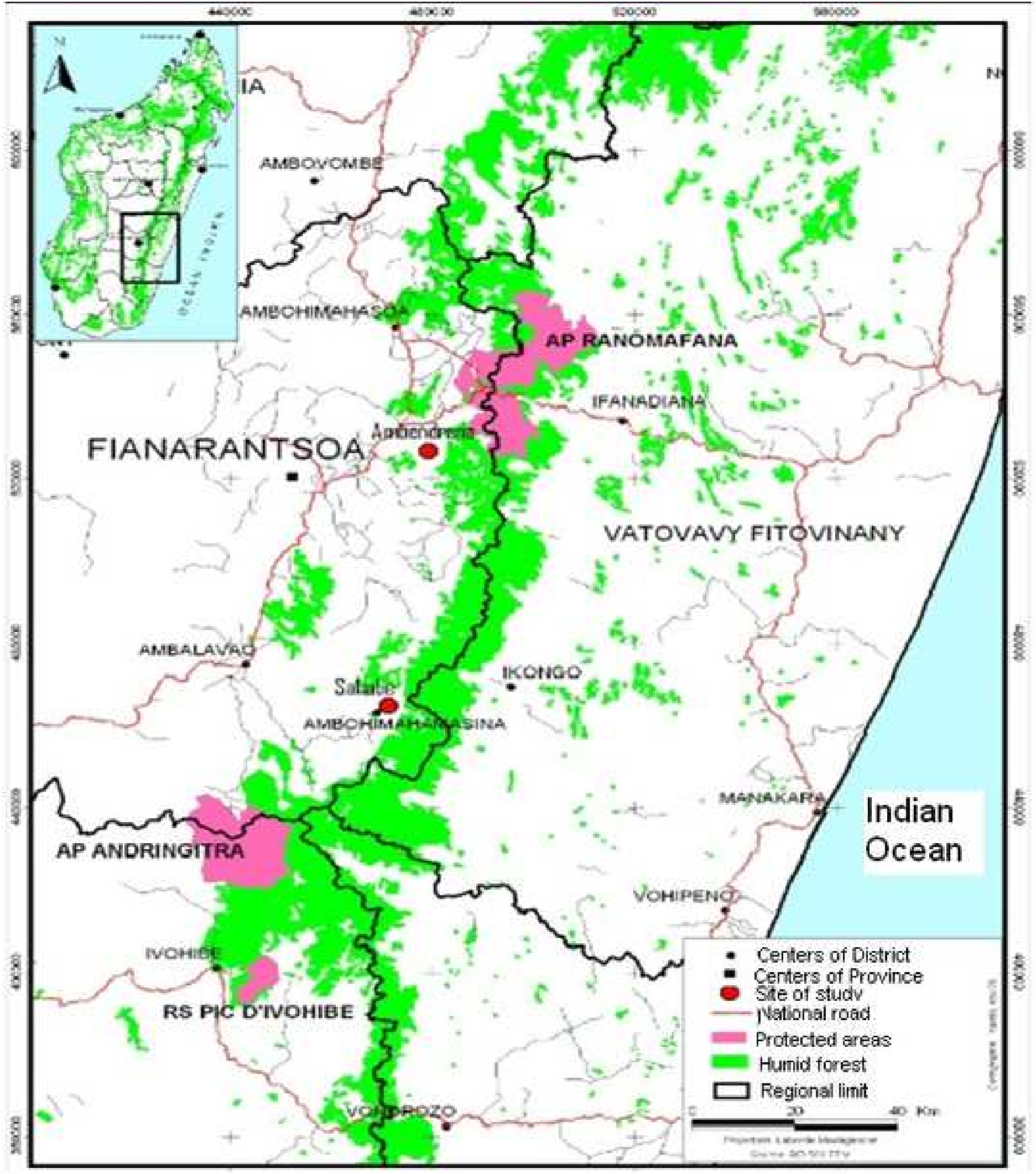


Click here to access/download;Figure;Fig 2.jpg $\underline{\underline{ }}$

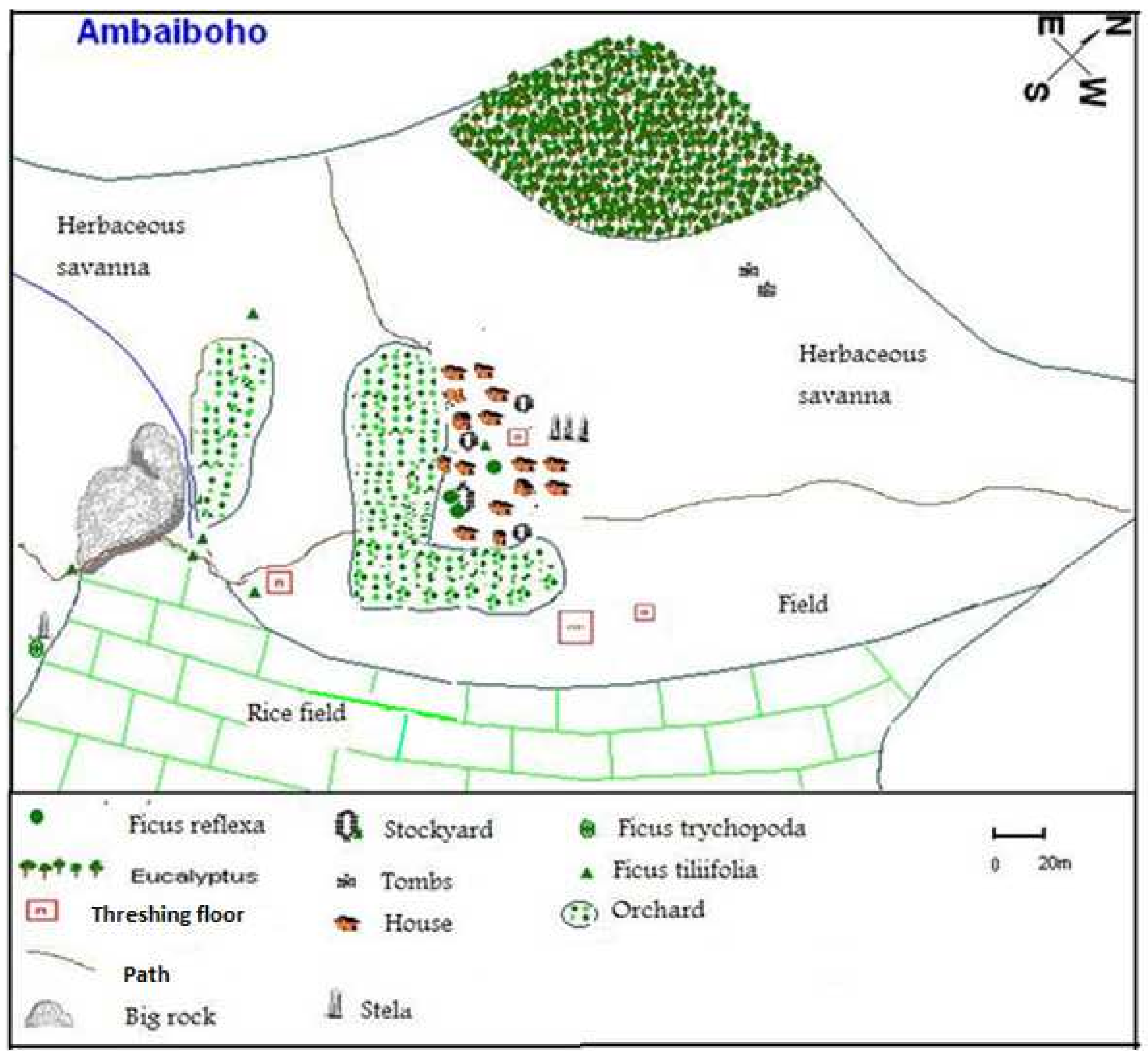




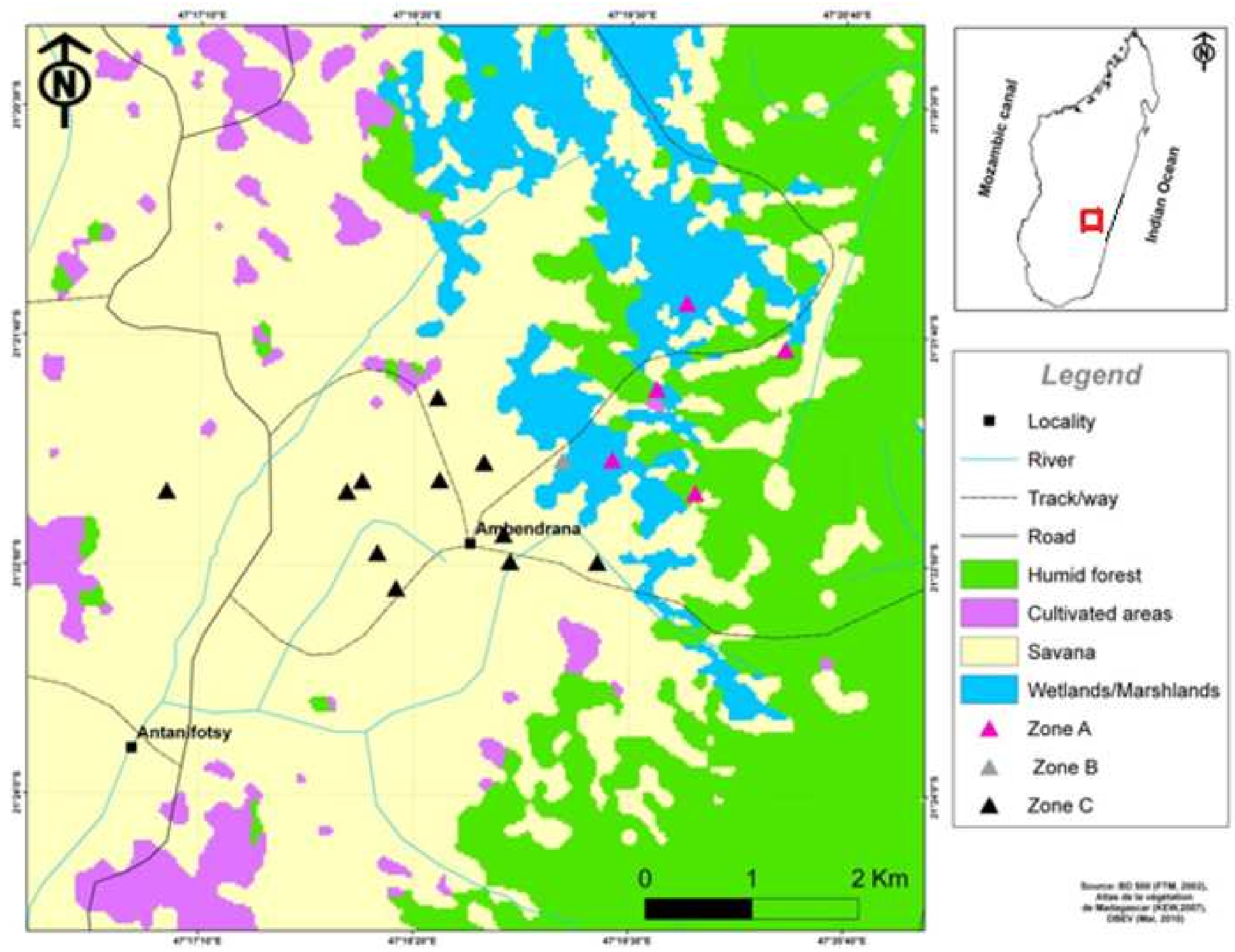


Click here to access/download;Figure;Fig 4.png $\underline{\underline{ \pm}}$

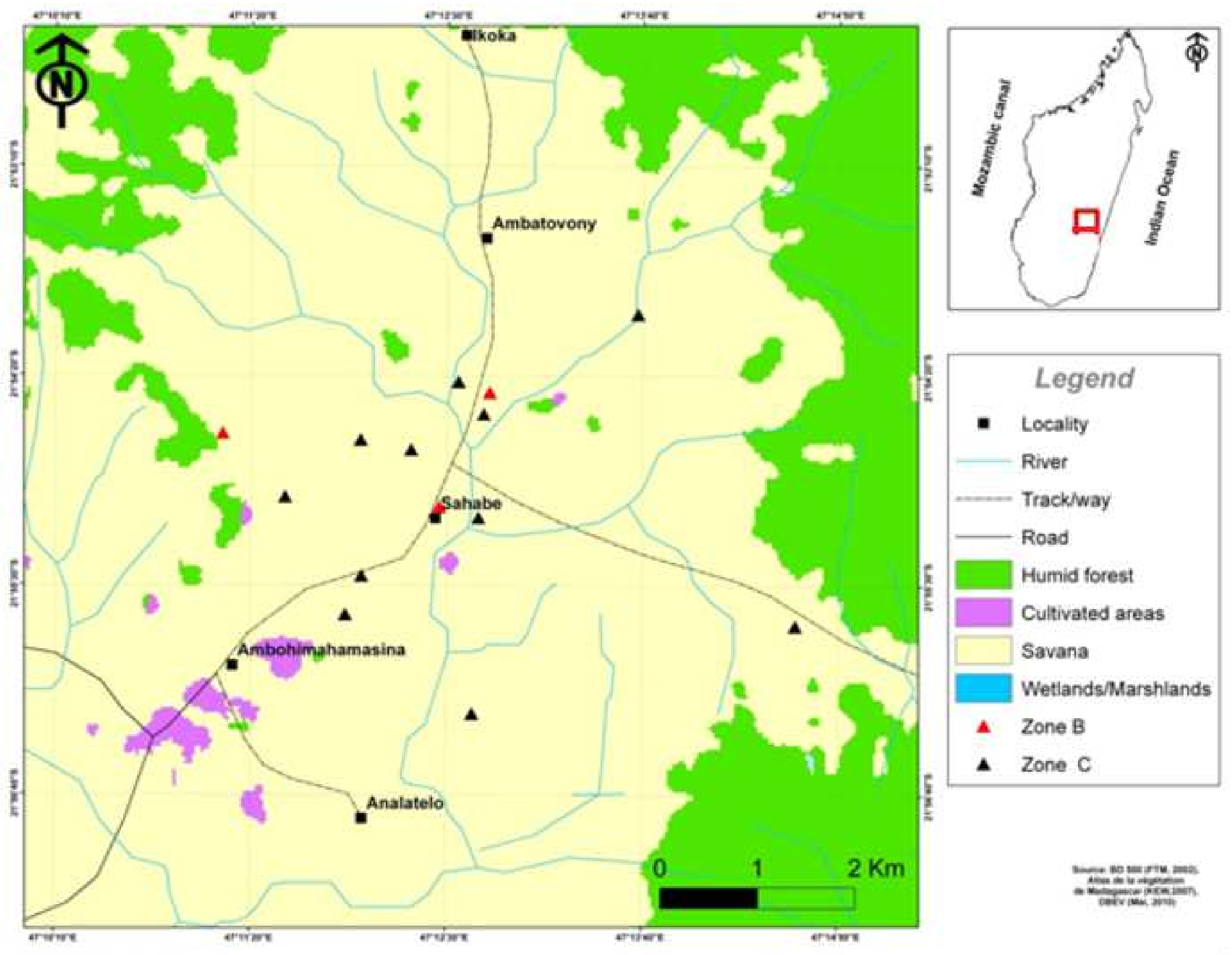




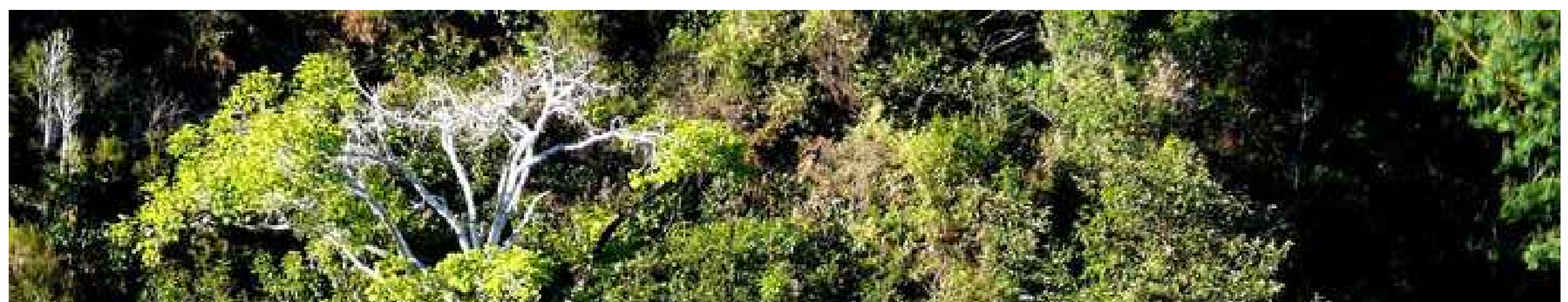

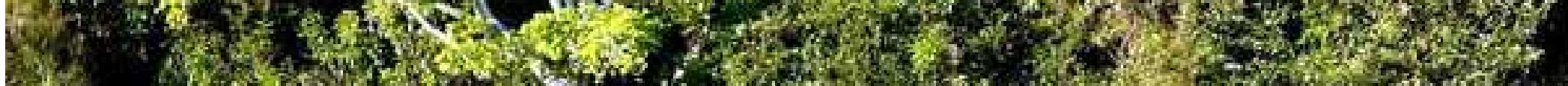
2. A.

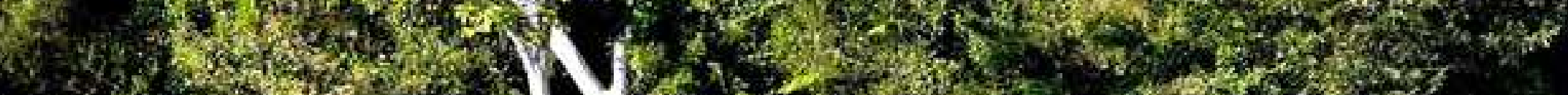

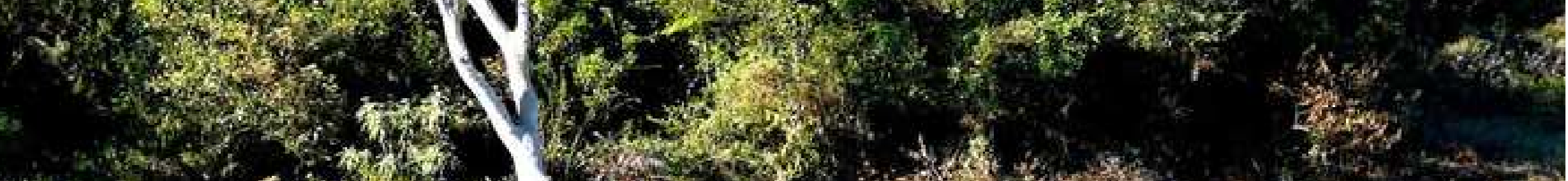

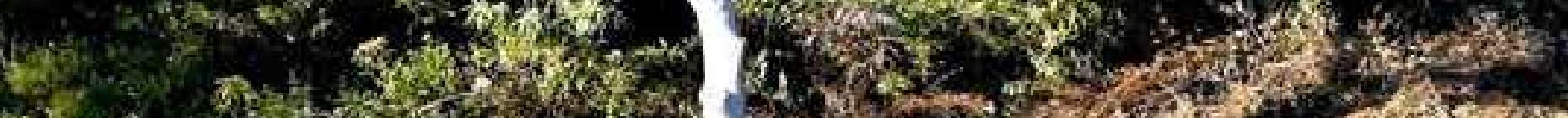

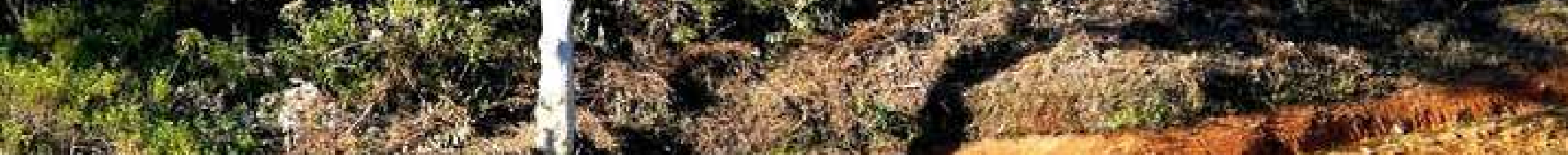

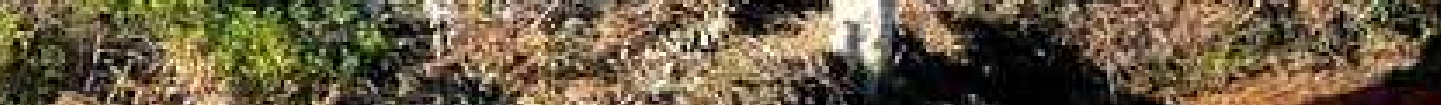
t.

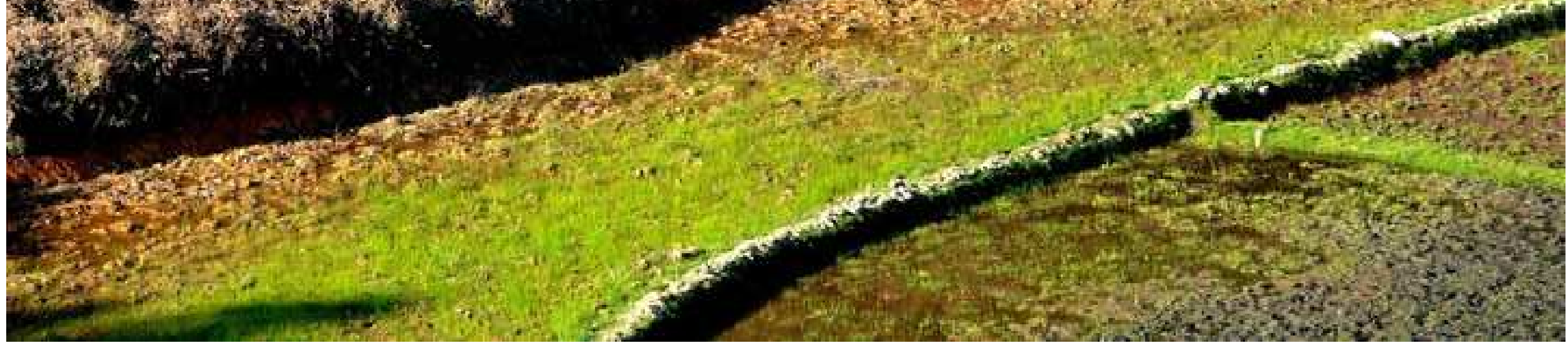

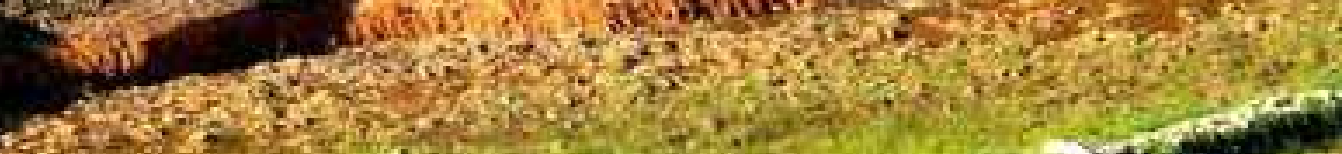

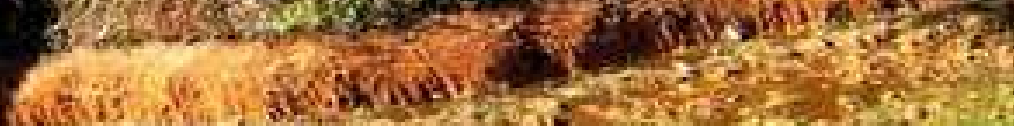




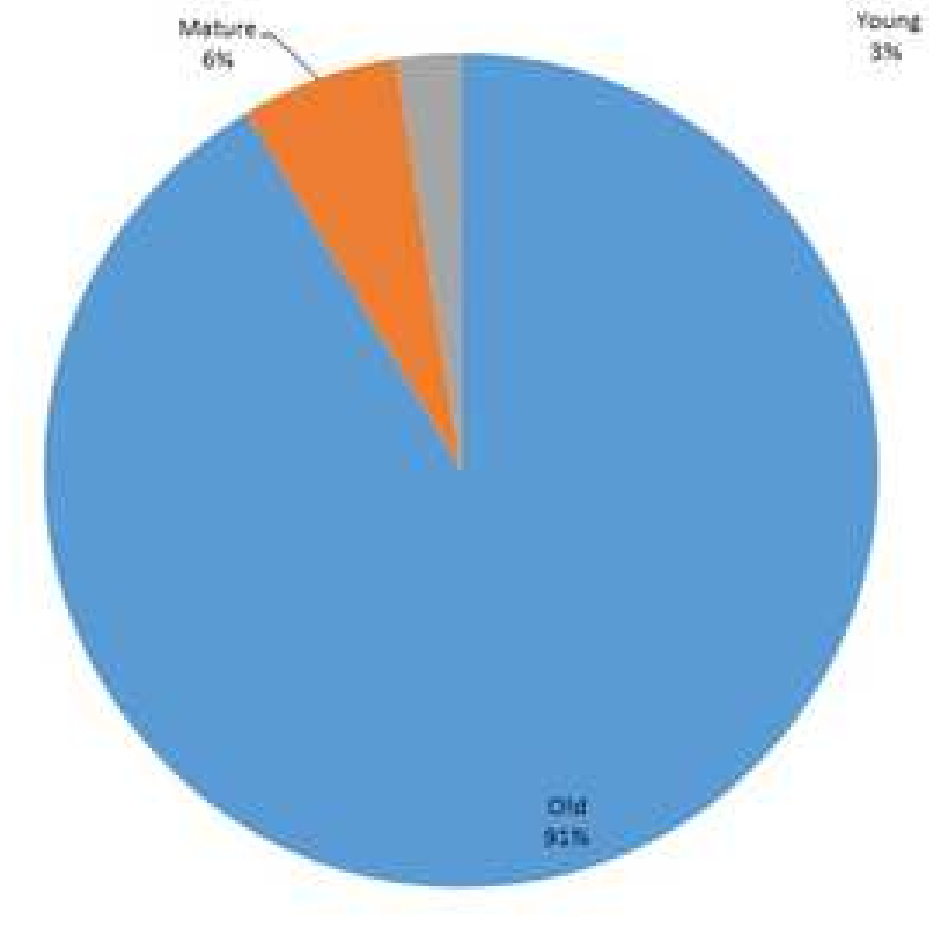

oune

Mats

.
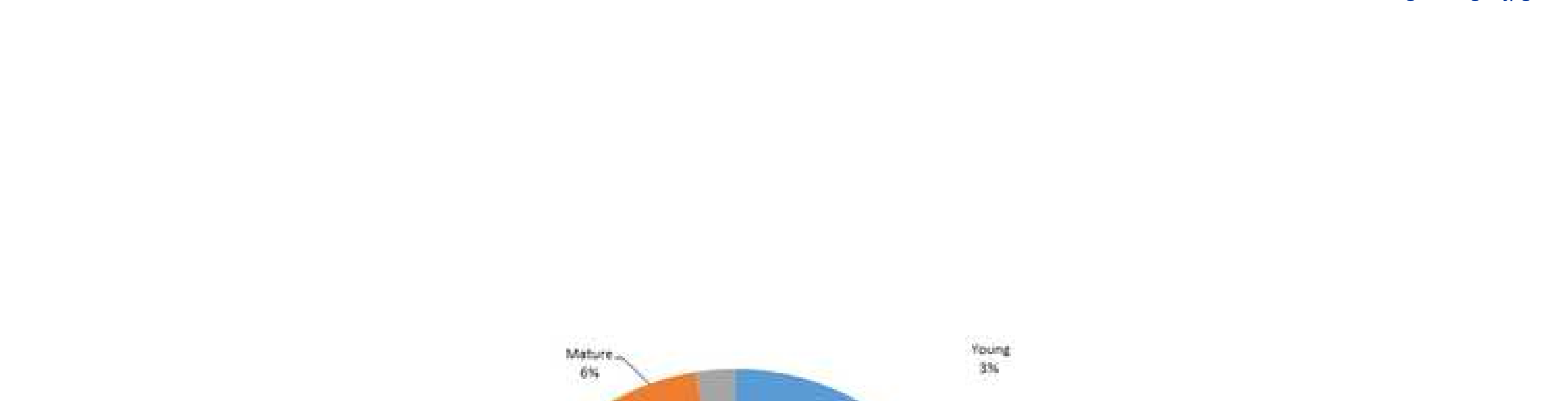
Fig.1 Location of the two study sites Ambendrana and SahabeRanomafana and Andringitra National Parks and the forest corridor, Madagascar 
Fig.2 Schematic representation of one hill with the elements of the landscape observed in Ambaiboho (Ambendrana) 
Fig.3 Localization of hills investigated in Ambendrana 
Fig.4 Localization of hills investigated in Sahabe 
Fig.5 Photo showing $F$. tiliifolia, saved from the forest on the edge of a paddy field 
Fig.6 Population structure of Ficus tiliifolia in Ambendrana and Sahabe 
Attachment to Manuscript

Click here to view linked References

Click here to access/download Attachment to Manuscript ESM_1.pdf 
Attachment to Manuscript

Click here to view linked References

Click here to access/download Attachment to Manuscript ESM_2.pdf 
Attachment to Manuscript

Click here to view linked References

Click here to access/download Attachment to Manuscript ESM_3.pdf 
Attachment to Manuscript

Click here to view linked References

Click here to access/download Attachment to Manuscript ESM_4.pdf 
Attachment to Manuscript

Click here to view linked References

Click here to access/download Attachment to Manuscript Title_page (1).docx 